\title{
Avian Cholera emergence in Arctic-nesting northern Common Eiders: using community-based, participatory surveillance to delineate disease outbreak patterns and predict transmission risk
}

\author{
$\underline{\text { Samuel A. Iverson }}^{1,2}, \underline{\text { Mark R. Forbes }}^{3}, \underline{\text { Manon Simard }}^{4}$, Catherine Soos $^{5,6}$ and $^{\text {H. Grant Gilchrist }}{ }^{7}$
}

\begin{abstract}
Emerging infectious diseases are a growing concern in wildlife conservation. Documenting outbreak patterns and determining the ecological drivers of transmission risk are fundamental to predicting disease spread and assessing potential impacts on population viability. However, evaluating disease in wildlife populations requires expansive surveillance networks that often do not exist in remote and developing areas. Here, we describe the results of a community-based research initiative conducted in collaboration with indigenous harvesters, the Inuit, in response to a new series of Avian Cholera outbreaks affecting Common Eiders (Somateria mollissima) and other comingling species in the Canadian Arctic. Avian Cholera is a virulent disease of birds caused by the bacterium Pasteurella multocida. Common Eiders are a valuable subsistence resource for Inuit, who hunt the birds for meat and visit breeding colonies during the summer to collect eggs and feather down for use in clothing and blankets. We compiled the observations of harvesters about the growing epidemic and with their assistance undertook field investigation of 131 colonies distributed over $>1200 \mathrm{~km}$ of coastline in the affected region. Thirteen locations were identified where Avian Cholera outbreaks have occurred since 2004. Mortality rates ranged from $1 \%$ to $43 \%$ of the local breeding population at these locations. Using a species-habitat model (Maxent), we determined that the distribution of outbreak events has not been random within the study area and that colony size, vegetation cover, and a measure of host crowding in shared wetlands were significantly correlated to outbreak risk. In addition, outbreak locations have been spatially structured with respect to hypothesized introduction foci and clustered along the migration corridor linking Arctic breeding areas with wintering areas in Atlantic Canada. At present, Avian Cholera remains a localized threat to Common Eider populations in the Arctic; however expanded, community-based surveillance will be required to track disease spread.
\end{abstract}

Key Words: Arctic; Avian Cholera; Common Eider; conservation; emerging infectious disease; Inuit; Maxent; participatory surveillance; species-habitat model

\section{INTRODUCTION}

Emerging infectious diseases are appearing at an unprecedented rate and pose a growing threat to global biodiversity (Daszak et al. 2001, Plowright et al. 2008). A poleward expansion of diseasecausing agents has been predicted in association with the effects of globalization and climate change (Harvell et al. 2002, Altizer et al. 2013). Reasons proposed to underlie this expansion include warming conditions in high latitude regions, making these regions more conducive to the growth and survival of pathogens, altered species ranges or movement behavior leading to new or increased contact between infected and previously disease-free populations, and human-mediated dispersal of pathogens facilitated by increased human activity (Kutz et al. 2005, Harvell et al. 2009). Arctic wildlife may be particularly vulnerable to introduced disease threats because many Arctic species are thought to have evolved in relative isolation, thereby placing limits on their immune capabilities for fending off novel infections in comparison with species that evolved in more pathogen-rich environments (Dobson 2009).

Recently Avian Cholera outbreaks have been reported at remote seabird breeding colonies located in the western Holarctic (Harms 2012, Bodenstein 2015). Avian Cholera is a highly virulent disease of birds caused by the bacterium Pasteurella multocida. The first accounts of Avian Cholera mass mortality involving wild birds were reported in close proximity to commercial poultry operations in the 1940s, and it has been hypothesized that $P$. multocida exchange at the wild bird-domestic bird interface is associated with the evolution and spread of highly virulent strains (Botzler 1991). Regardless, the disease is now entrenched in the wild bird reservoir and appears to be expanding its host range and geographic distribution within waterfowl and colonial nesting seabird populations (Crawford et al. 1992, Österblom et al. 2004, Waller and Underhill 2007).

To date, Avian Cholera outbreaks in the Canadian Arctic have primarily affected Common Eiders (Somateria mollissima) (Harms 2012). The Common Eider is a large-bodied sea duck that spends the majority of its annual cycle in the marine environment and comes ashore only to breed (Goudie et al. 2000). The Northern Common Eider subspecies ( $S . m$. borealis) nests throughout west Greenland and the eastern Canadian Arctic and winters off the coasts of southwestern Greenland, Labrador, and Newfoundland, and the Gulf of St. Lawrence, Québec. Outbreaks affecting Northern Common Eiders have been identified as a conservation concern because of the high degree of mortality noted during the initial wave of pathogen invasion and the recurrent nature of outbreaks at some locations (Buttler et al. 2011, Descamps et al. 2012, Iverson et al. 2016). Although Avian Cholera has been known for several decades to circulate in

${ }^{1}$ Department of Biology, Simon Fraser University, ${ }^{2}$ Canadian Wildlife Service, Environment and Climate Change Canada, ${ }^{3}$ Department of Biology, Carleton University, ${ }^{4}$ Nunavik Research Centre, Makivik Corporation, Kuujjuaq, ${ }^{5}$ Science and Technology Branch, Environment and Climate Change Canada, ${ }^{6}$ Department of Veterinary Pathology, University of Saskatchewan, ${ }^{7}$ National Wildife Research Centre, Environment and Climate Change Canada 
Common Eider breeding populations that nest in temperate regions of eastern North America (American Common Eider subspecies S. m. dresseri; Reed and Cousineau 1967, Korschgen et al. 1978, The Joint Working Group on the Management of the Common Eider 2004) and western Europe (European Common Eider subspecies S. m. mollissima; Swennen and Smit 1991, Christensen et al. 1997), the disease's appearance in Northern Common Eiders appears to be a new phenomenon (Harms 2012).

Determining the ecological factors that drive disease emergence is crucial for predicting outbreak risk, evaluating conservation threat, and devising effective control strategies (Smith et al. 2002, Liu et al. 2013). However, disease assessment in wild, free-ranging animal populations requires expansive surveillance networks, which often do not exist in geographically remote and developing regions like the Arctic (Brook et al. 2009). In such regions, indigenous harvesters are often the first to notice environmental change that influences the health of species upon which they depend for subsistence (Berkes et al. 2000, Kutz et al. 2009). In the Canadian Arctic, indigenous participation in ecological monitoring and the inclusion of traditional and local ecological knowledge in decision making have become fundamental components of wildlife comanagement (Gilchrist et al. 2005, Berkes 2007, Kowalchuk and Kuhn 2012) and have increasingly contributed to wildlife disease surveillance (Brook et al. 2009, Parlee et al. 2014).

Inuit in Canada are often very familiar with the location and status of Common Eider populations near their communities. Inuit hunt eiders for meat during the nonbreeding season and visit breeding colonies to collect eggs and feather down for use in clothing and blankets (Nakashima 1991, Gilchrist et al. 2005). Eider feather down is a particularly valued resource because it can be collected noninvasively from nests and fetches a high price in world markets (Skarphédinsson 1996). Indeed, Inuit eider down collectors were the first to report Avian Cholera mortality in the region (Kwan 2004). Local ecological knowledge interviews were conducted with harvesters following the documentation of these initial outbreaks (Henri et al. 2010), and wildlife authorities in Nunavik (northern Québec) worked with local harvesters to map outbreak locations (M. Simard, Nunavik Research Centre, unpublished data).

Here, we build upon these efforts and present the results of a research initiative designed to compile Inuit observations about past outbreak events in a standardized database and to conduct investigative surveys with Inuit participation across the affected region to search for evidence of new, ongoing, or unreported mortality. Our specific research aims were to (1) determine the frequency of outbreak events and current spatial extent of the epidemic, (2) quantify the magnitude of mortality of eiders and other species associated with the die-off events, and (3) assemble information about the biophysical and avian community attributes of eider colonies both with and without a history of Avian Cholera occurrence for use in a predictive species-habitat model, Maxent (Maximum Entropy Species Distribution Modeling; Philips et al. 2006). We used the model to identify ecological correlates of outbreak occurrence, a critical first step to risk mapping and predicting the potential for further disease spread (Slater and Michael 2012, Liu et al. 2013, Mweya et al. 2013). Our findings are relevant for understanding the threat posed by Avian Cholera to viability of Northern Common Eider populations, identifying transmission hot spots and host species involved in the geographic spread and maintenance of disease, and acting as a template for conducting community-based, participatory research in the Canadian Arctic specifically and other remote, developing areas more generally.

\section{METHODS}

\section{Host-pathogen ecology}

P. multocida infections are spread between birds through direct contact and indirectly through the ingestion or inhalation of bacteria in contaminated water or sediments. Infections produce respiratory and septicemic disease, often with a rapid onset of morbidity (Botzler 1991, Friend 1999, Samuel et al. 2007). Acute Avian Cholera infections can result in bird death within 6-12 h of exposure, and it is not uncommon to find diseased birds dead on their nest when outbreaks occur at breeding sites (Friend 1999).

Serological investigations have proven effective for detecting recent infections, and vaccination studies suggest that at least short-term immunity is likely for surviving individuals (Samuel et al. 2005). P. multocida is known to remain infective in wetlands for a period of days to months (Friend 1999, Samuel et al. 2007); however, it does not appear to overwinter in the environment (Samuel et al. 2004, Blanchong et al. 2006). Instead, carrier birds are thought to play an essential role in the cross-seasonal perpetuation and geographic dispersal of the disease (Samuel et al. 2005).

Common Eiders nest primarily on small near-shore islands in aggregations that range in size from a few birds to several thousand individuals (Goudie et al. 2000). Most of the Avian Cholera outbreaks affecting Common Eiders have been documented in temperate regions have occurred on breeding colonies, where high host densities are thought to amplify transmission probability (Samuel et al. 2007). Female eiders exhibit a high degree of natal philopatry and incubate eggs without male assistance. In the Arctic environment, nesting phenology is tightly correlated with the timing of spring sea ice breakup (Love et al. 2010). Collectively, these traits result in a high degree of behavioral synchrony, spatial crowding, and the intensive use of a shared environment by reproductive females. However, there is substantially less contact, and by extension potential for disease transmission, involving males or immature birds during the breeding period.

Prior to our research initiative, Avian Cholera outbreaks affecting the Northern Common Eider were confirmed by laboratory analysis from four locations in the Hudson Strait region of the Canadian Arctic. In each case, large numbers of newly dead birds ( $>20$ carcasses) were observed within eider breeding colonies, and tissue samples were collected from carcasses for analysis at national laboratories (Canadian Cooperative Wildlife Health Centre 2007, Harms 2015). One of these breeding colonies was at a long-term bird monitoring station administered by Environment and Climate Change Canada, located off the eastern coast of Southampton Island, Nunavut (Mitivik Island: $64.030 \mathrm{~N}, 81.789 \mathrm{~W}$ ). Avian Cholera outbreaks on Mitivik Island occurred annually from 2005 to 2012 (Iverson et al. 2016). The other three locations were on the northern coastline of Québec in Nunavik, where mortality events were detected by Inuit eider 
down collectors from the communities of Ivujivik, Kangiqsujuaq, and Aupaluk in 2004 and 2006. Before the arrival of Avian Cholera in the study system, die-offs of this kind were regarded as wholly unprecedented by both biologists and Inuit harvesters (Henri et al. 2010).

\section{Inuit consultation}

Members of our research team have been involved in seabird monitoring and conservation in the Canadian Arctic in collaboration with Inuit partners for many years (Mallory et al. 2003, Gilchrist et al. 2005, Gilchrist and Mallory 2007). We initiated field operations for this study in 2010 and conducted field surveys during the summers of 2010 through 2013. We selected six communities as bases of operations: Cape Dorset, Iqaluit, Aupaluk, Kangirsuk, Kangiqsujuaq, and Ivujivik (Fig. 1). These locations provided comprehensive coverage of the study area and included sites both with and without a documented history of Avian Cholera occurrence.

Fig. 1. Map of the study area. Numbered boxes indicate survey zones, and the triangle represents the location of the Mitivik Island long-term bird monitoring site.

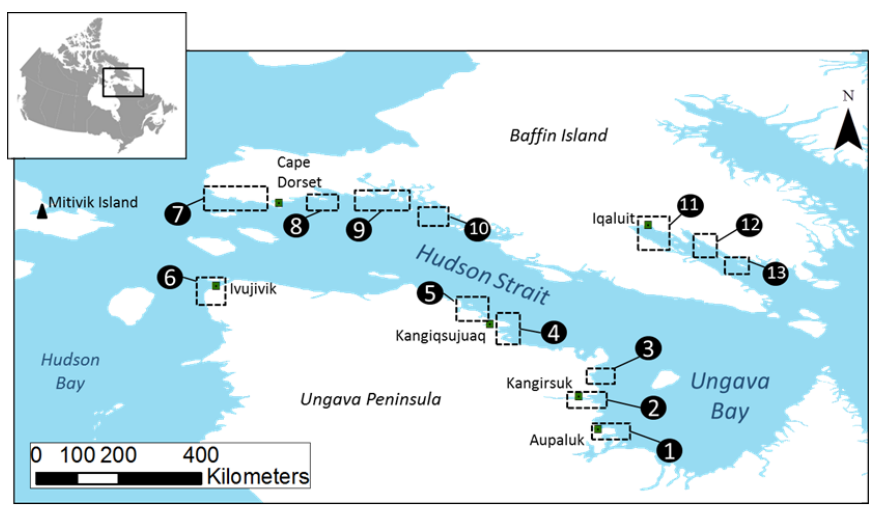

Before undertaking field surveys, we made presentations to wildlife comanagement boards chaired by Inuit directors in Nunavut (Nunavut Wildlife Management Board) and Nunavik (Nunavik Marine Region Wildlife Management Board), and also to local Hunters Fishers and Trappers Association (HFTA) chapters in the communities where we proposed to work. The purpose of our presentations was to share information about the emerging threat posed by Avian Cholera to Arctic bird populations, solicit input about what has been observed locally, and obtain permits and logistical support to conduct our research. We were assisted in our presentations by Inuktitut interpreters and used slides and printed materials containing photographic images of healthy and diseased birds to guide our conversations.

HFTA directors were our primary point of contact for engaging with local harvesters. They also identified community members with access to boats and camping equipment suitable for our needs who could act as guides. We informally interviewed the harvesters to obtain their recollections about the location and status of eider colonies near their communities. We obtained verbal consent to use the information they shared and enlisted them to join our research team as paid members when traveling to the colonies for site visits.
Our meetings occurred during late winter and early spring, approximately one to four months before field operations.

\section{Survey design}

On the basis of the information that we received in our community consultations, we delineated 13 survey zones for intensive study (Fig. 1). Within these zones, we investigated all islands known to contain eider colonies numbering 20 or more breeding pairs. In most cases, the islands that we surveyed were locations where breeding bird surveys had been conducted previously by Canadian Wildlife Service biologists, typically with Inuit assistance (Gaston et al. 1985, Chapdelaine et al. 1986, Cooch 1986, Hipfner et al. 2002, Falardeau et al. 2003; H. G. Gilchrist and J. Akearok, Environment Canada, unpublished data). We added islands not included in the Canadian Wildlife Service database that were identified by our Inuit partners as locations where they routinely collected eider feather down or were aware had nesting colonies that were not marked on our maps. Further details about site selection, including 1:50,000 scale topographic maps of each survey zone, are provided as online supplemental material (Appendix 1).

Field work was timed to occur during mid-July, when female eiders are on shore incubating nests. Survey dates were 10-26 July 2010, 6-19 July 2011, 8-21 July 2012, and 7-24 July 2013 (Appendix 1 , Table A1.1). When conducting the surveys, we traveled between islands by boat. Standard Canadian Wildlife Service protocols were followed for making breeding bird population estimates (Robertson and Gilchrist 1998, Falardeau et al. 2003). Complete censuses were undertaken because there is little emergent vegetation in the study area and the islands preferred by nesting eiders are generally small in size $\left(<2 \mathrm{~km}^{2}\right)$. On each island, a team of three to eight people walked successive linear sweeps through the nesting area and counted eider nests, which are highly visible because female eiders line their nest bowls with plucked downy feathers.

In addition to counting eider nests, we recorded the species' identity and number of any other nesting birds that we encountered. We also noted the identity and number of any birds that were not obviously associated with a nest when traveling on islands or boating between islands, up to a distance of $5 \mathrm{~km}$ from the boat landing and departure site. We also searched for evidence of past mortality (skeletal remains) or ongoing mortality (fresh carcasses). All carcasses were collected, preserved on ice, and submitted to the Canadian Cooperative Wildlife Health Centre for diagnostic testing. We estimated percent vegetation cover based on visual assessment. Predominant vegetation included sedge, cotton grass, and bog rush (family Cyperaceae), and a variety of mosses (class Bryopsida). We counted the number of freshwater ponds $>10 \mathrm{~m}^{2}$ in area. Finally, we recorded latitude and longitude on each island to facilitate geo-referencing and the integration of remotely sensed land cover information with field data.

\section{Data analysis}

Recognizing that laboratory diagnoses were not made for all of the dead birds that we or our Inuit partners discovered, we rated the evidence that a past or ongoing mortality event could be ascribed to Avian Cholera using three mutually exclusive categories: 
1. Confirmed outbreak, indicating that a mass mortality event involving $\geq 20$ dead eiders was either reported by an Inuit harvester or discovered during our survey, wherein tissue samples were collected from at least one bird that tested positive for P. multocida by genetic or serological methods;

2. Suspected outbreak, indicating that a mass mortality event involving $\geq 20$ dead eiders was reported by an Inuit harvester prior to the arrival of our team and corroborating evidence was found during our survey in the form of skeletal remains; however, no samples were collected at the time of the outbreak for laboratory analysis; or

3. No outbreak apparent, indicating that mass mortality involving $\geq 20$ dead eiders was not reported by Inuit harvesters, nor was there any evidence of a past or ongoing mass mortality observed during our survey.

For the purpose of our analyses, we treated confirmed and suspected outbreaks identically and note that in all instances when Inuit harvesters reported the occurrence of a mass mortality event, we were able to validate the event by discovery of skeletal remains. However, we acknowledge uncertainty with respect to cause of death in all birds. Although unlikely, it is possible multiple factors contributed to die-off events (e.g., coinfection by more than one pathogen) or that other, as yet unidentified, highly virulent pathogens are circulating in the population.

\section{Distribution of outbreaks, host species range, and extent of mortality}

The first portion of our analysis was largely descriptive and involved compiling information shared by Inuit harvesters about past outbreak events and integrating these data with the information gathered in our surveys. Quantities of interest included the outbreak locations, dates of occurrence, species present, and the species identity and number of dead birds. In addition, for eiders, we approximated percent mortality by dividing the number of carcasses reported by the number of nests counted during our follow-up survey. This provided a rough approximation of the minimum female mortality rate. Our metric was influenced by imperfect detectability of carcasses, the accuracy of harvester recollections, and the existence of a temporal lag between the time of outbreak occurrence and colony size estimation. However, we regarded this quantity as useful for inferring the magnitude of the population injury that was sustained and for assessing the degree to which Avian Cholera should be considered a conservation threat.

\section{Species-habitat model (Maxent)}

The second portion of our analysis used a predictive specieshabitat model, Maxent (Maximum Entropy Species Distribution Modeling, version 3.3.3k; Phillips et al. 2006), to identify ecological correlates of outbreak risk. Maxent is a presence-only modeling approach that uses a machine learning algorithm to extract associations between presence data and a random sample of (pseudo-absence) background sites. It is used as an alternative to models that assume a lack of detection is indicative of true absence and is widely employed in situations where absence records are either unavailable because of sampling design or unreliable because of uncertain detectability (Phillips et al. 2006, Elith et al. 2011). In recent years, the program has seen an increase in use in studies of wildlife disease distribution, where it is recognized that infection status is, by nature, a temporally dynamic process and the capacity of researchers to detect past or ongoing infections is imperfect (Slater and Michael 2012, Liu et al. 2013, Mweya et al. 2013). The model enables users to identify dependencies between infection presence and predictor variables, which in turn can be used to characterize the environmental conditions most conducive to supporting an outbreak and thereby also predict outbreak risk at locations not surveyed (e.g., Slater and Michael 2012).

For our analysis, we treated the set of confirmed and suspected Avian Cholera outbreak locations as presence records, while the complete set of eider colonies that we surveyed were treated as background sites. We used a tiered approach in which we began by evaluating the relative importance of candidate variables within categories of similar data types, and then made crosscategory comparisons of the best-supported variables in the firststage analyses. Three categories were considered: (1) biophysical attributes of islands on which colonies were located, (2) focal host quantitites, and (3) potential disease dispersers. Brief descriptions of the explanatory variables included in each category are provided below and in Table 1. Additional details concerning their parameterization are provided as an online digital supplement (Appendix 2).

Table 1. Variables examined to identify ecological predictors of Avian Cholera outbreak probability at Common Eider (Somateria mollissima) breeding colonies.

\begin{tabular}{|c|c|c|}
\hline Variable & Description & Units \\
\hline \multicolumn{3}{|c|}{ Biophysical attributes of islands with eider colonies present } \\
\hline pPOND & Presence of ponds $\left(>10 \mathrm{~m}^{2}\right)$ & $0 / 1$ \\
\hline$n P O N D$ & Number of ponds $\left(10 \mathrm{~m}^{2}\right)$ & Count \\
\hline$V E G$ & $\begin{array}{l}\text { Proportion of island covered by } \\
\text { vegetation }\end{array}$ & $0-1$ \\
\hline ELEV & Maximum elevation contour of island & M \\
\hline$A R E A$ & Size of the island & ha \\
\hline \multicolumn{3}{|c|}{ Focal host quantities } \\
\hline nCOEI & Number of Common Eider nests & Count \\
\hline$d C O E I$ & Density of Common Eider nests & Pairs $* \mathrm{ha}^{-1}$ \\
\hline$(P / 100 E)^{2}$ & $\begin{array}{l}\text { Ponds per } 100 \text { Common Eider nests } \\
\text { (quadratic feature) }\end{array}$ & Ponds/host \\
\hline \multicolumn{3}{|c|}{ Disease dispersers } \\
\hline pHERG & $\begin{array}{l}\text { Presence of American Herring Gull } \\
\text { (Larus smithsonianus) nests }\end{array}$ & $0 / 1$ \\
\hline$p G L G U$ & $\begin{array}{l}\text { Presence of Glaucous Gull (Larus } \\
\text { hyperboreus) nests }\end{array}$ & $0 / 1$ \\
\hline$n H E R G$ & $\begin{array}{l}\text { Number of American Herring Gull } \\
\text { nests }\end{array}$ & Count \\
\hline$n G L G U$ & Number of Glaucous Gull nests & Count \\
\hline$a G U L L$ & Gulls counted within $5 \mathrm{~km}$ of island & Count \\
\hline COEI-CF & Common Eider —Canada flyway & Paths per $\mathrm{km}^{2}$ \\
\hline$C O E I-G F$ & Common Eider-Greenland flyway & Paths per $\mathrm{km}^{2}$ \\
\hline$S N G O$ & $\begin{array}{l}\text { Lesser Snow Goose (Chen caerulescens } \\
\text { caerulescens) - Midcontinent flyway }\end{array}$ & $0 / 1$ \\
\hline
\end{tabular}

Biophysical attributes. Because Avian Cholera can be transmitted indirectly in contaminated water, freshwater melt ponds located on colonies are a potential source of transmission and prospective focal point of management intervention (Botzler 1991). Therefore, we quantified pond presence $(p P O N D)$ and number 
$(n P O N D)$ as potential predictor variables. We also evaluated other site characteristics that influence drainage and the way birds access and use the habitat, including percent vegetation cover $(V E G)$, island size $(A R E A)$, and elevation ( $E L E V)$. Pond presence, pond number, and vegetation cover were derived from visual assessments made in the field, whereas island size and elevation were determined by querying digital thematic maps (CanVec 1:50,000 scale topographic) in ArcGIS (Version 10.1; Environmental Systems Research Institute Inc., Redlands, California, USA).

Focal host quantities. Botzler et al. (1991) identified two levels at which host numbers potentially influence Avian Cholera transmission: (1) via an increased probability of bacterial presence in infected hosts or the environment with increasing host abundance and (2) via a higher contact rate with increasing host density. In our models, we included measurements of eider abundance ( $n C O E I$ : nests per island) and density ( $d C O E I$ : nests per ha), as well as a quadratic feature for the ratio of pond abundance per eider $(P / 100 E)^{2}$ as predictor variables. The latter was parameterized as the square of the number of ponds per 100 nesting eiders and was included so that nonlinear variations in outbreak probability could be considered in relation the number of birds sharing a common water source, a potentially more informative measurement of host density effects than simply the number of birds per unit area.

Potential disease dispersers. Our interest here was to evaluate the evidence that different species or populations played a role in bringing the pathogen to Northern Common Eider breeding colonies or helped to spread disease among colonies once it arrived. Harms (2012) advanced several possibilities. The first is that the disease spilled over from American Common Eiders to Northern Common Eiders on shared wintering areas, via either direct contact or through an intermediary species, and Northern Common Eiders subsequently brought the disease northward during spring migration. Avian Cholera has circulated in the American Common Eider population for at least 50 years (The Joint Working Group on the Management of the Common Eider 2004), and during the nonbreeding season the Northern and American Common Eider subpopulations have broadly overlapping ranges in the Gulf of St. Lawrence. Another potential vector of long-distance pathogen dispersal identified by Harms (2012) is Lesser Snow Geese (Chen caerulescens caerulescens). Lesser Snow Geese are well-documented hosts of Avian Cholera that are capable of surviving infection and spreading disease to new locations (Samuel et al. 2005). Lesser Snow Geese overwinter in the central United States and have partially overlapping breeding ranges with Northern Common Eiders in the eastern Canadian Arctic. Finally, large-bodied gulls (Larus spp.) have been implicated in Avian Cholera die-offs off at offshore sites in Newfoundland (Wille et al. 2016). Gulls frequently nest on the same islands used by Common Eiders and have been identified as important intermediary hosts in the transmission of other avian diseases (Arnal et al. 2015).

We predicted that if a proposed disperser indeed had a role in the transmission of Avian Cholera, then the species' or populations' summer distribution pattern should be spatially correlated with outbreak locations. To evaluate this prediction for Northern Common Eiders, we used data from satellite telemetry studies by
Mosbech et al. (2006), Savard et al. (2011), and H. G. Gilchrist, Environment Canada (unpublished data). These authors provided location information for eiders during spring migration. We used the data to quantify the intensity of shoreline use in the Hudson Strait by birds arriving from wintering areas in either Atlantic Canada (COEI-CF) or west Greenland (COEI-GF), based on the number of paths per square kilometer for a sample of 29 marked individuals. For Lesser Snow Geese $(S N G O)$, we obtained breeding range distribution maps from the U.S. Fish and Wildlife Service (U.S. Fish and Wildlife Service 2007). For the gull species, variables of interest included the presence and number of nesting American Herring Gulls (L. smithsonianus; pHERG, nHERG), the presence and number of nesting Glaucous Gulls ( $L$. hyperboreus; $p G L G U, n G L G U$ ), and the total number of all Larus gulls observed on the ground, in the air, or on the water irrespective of their nesting status within $5 \mathrm{~km}$ of each focal colony ( $a G u l l)$.

Both the presence and background data sets were parsed to include only colonies with $\geq 20$ eider nests to reduce detection bias for outbreak identification. When implementing our models, we used Maxent's samples-with-data format, which is appropriate in situations where spatially explicit data are combined with nongridded attributes (Elith et al. 2011). To avoid over-fitting the data, we restricted our evaluation primarily to linear features (Barry and Elith 2006).

To validate our model, we used cross-validation to calculate an area under the receiver operating characteristic curve (AUC) with a standard deviation (Elith et al. 2011). The cross-validation approach divides the data set of presence records into "training" and "test" subsets, using the training data to construct the model and determine the functional relationship between presence localities and environmental variables. The remaining test data are then used to assess the predictive ability of the model. Following recommendations by Pearson et al. (2007) for data sets with a small sample size, we combined cross-validation with a jackknife procedure, wherein a single presence locality is withheld at a time from the training data and the model is built using the remaining $n-1$ localities. Hence, in a situation with $n$ presence records, $n$ separate models are built and predictive performance is determined based on the proportion of withheld samples correctly identified as presence sites. The key to interpreting variable predictiveness is to assess AUC gain when the variable in question is included in a candidate set of variables (percent contribution) or lost when it is withheld (permutation importance). An AUC value close to 0.5 indicates that fit is no better than random, whereas a value of 1.0 indicates a perfect fit.

\section{RESULTS}

\section{Spatial distribution of outbreaks, host species range, and magnitude of mortality}

In total, we investigated 299 islands that met our suitability criteria for eider nesting, of which 131 islands contained $\geq 20$ eider nests, which was the lower threshold for inclusion in the species-habitat model (Appendix 1, Table A1.1).

We identified 13 colonies where confirmed or suspected Avian Cholera outbreaks occurred (Fig. 2). Outbreak years were 2004, 2006,2011 , and 2013. Eleven of the outbreaks were originally discovered by Inuit harvesters, ten of which occurred before our research team conducted its site surveys and one after our team 
Table 2. Avian Cholera outbreak locations, species implicated in die-offs, and percent mortality of nesting female Common Eiders (Somateria mollissima). See Table A1.2 and Fig A1.1- A1.12 for additional location details.

\begin{tabular}{|c|c|c|c|c|c|c|c|}
\hline $\begin{array}{l}\text { Outbreak } \\
\text { ID }\end{array}$ & Year & Survey zone & Classification & $\begin{array}{l}\text { Species identified in the } \\
\text { die-off }^{\dagger}\end{array}$ & $\begin{array}{l}\text { Number of dead } \\
\text { Common Eiders }\end{array}$ & $\begin{array}{l}\text { Number of } \\
\text { eider nests }\end{array}$ & $\begin{array}{c}\text { Minimum } \\
\text { percent } \\
\text { mortality }\end{array}$ \\
\hline 1 & 2004 & Digges Sound & Confirmed & COEI, GLGU, BLGU & 62 & 231 & $27 \%$ \\
\hline 2 & 2004 & Digges Sound & Suspected & $\begin{array}{l}\text { COEI, BLGU, goose } \\
\text { spp. }\end{array}$ & 84 & 228 & $37 \%$ \\
\hline 3 & 2004 & Digges Sound & Suspected & $\begin{array}{l}\text { COEI, BLGU, goose } \\
\text { spp. }\end{array}$ & 75 & 174 & $43 \%$ \\
\hline 4 & 2004 & Mansel Island & $\begin{array}{c}\text { Unconfirmed } \\
\text { (not investigated) }\end{array}$ & - & - & - & - \\
\hline 5 & 2004 & Nottingham Island & $\begin{array}{c}\text { Unconfirmed } \\
\text { (not investigated) }\end{array}$ & - & - & - & - \\
\hline 6 & 2006 & Ikkatuk Bay & Confirmed & COEI, BLGU, GBBG & 41 & 317 & $13 \%$ \\
\hline 7 & 2006 & Payne Bay & Suspected & COEI & 50 & 227 & $22 \%$ \\
\hline 8 & 2006 & Payne Bay & Suspected & COEI & 50 & 542 & $9 \%$ \\
\hline 9 & 2006 & Payne Bay & Suspected & COEI & 50 & 805 & $6 \%$ \\
\hline 10 & 2006 & Joy Bay & Confirmed & COEI & 250 & 1054 & $24 \%$ \\
\hline 11 & 2006 & Joy Bay & Confirmed & COEI & 36 & 322 & $11 \%$ \\
\hline 12 & 2006 & Joy Bay & Confirmed & COEI & 309 & 1292 & $24 \%$ \\
\hline $13 \mathrm{a}$ & 2006 & King George Sound & Suspected & COEI & 55 & 1840 & $1 \%$ \\
\hline $13 b$ & $2011^{*}$ & King George Sound & Suspected & $\begin{array}{l}\text { COEI, BLGU, CAGO, } \\
\text { HERG, GLGU }\end{array}$ & 21 & 1840 & $1 \%$ \\
\hline 14 & 2008 & Digges Sound & $\begin{array}{c}\text { Unconfirmed } \\
\text { (not investigated) }\end{array}$ & - & - & - & - \\
\hline 15 & 2011 & Ikkatuk Bay & Confirmed & $\begin{array}{l}\text { COEI, HERG, BLGU, } \\
\text { NOPI }\end{array}$ & 39 & 223 & $17 \%$ \\
\hline 16 & 2013 & King George Sound & Suspected & COEI & 25 & 158 & $16 \%$ \\
\hline
\end{tabular}

${ }^{\top}$ Species codes: BLGU, Black Guillemot (Cepphus grylle); CAGO, Canada Goose (Branta canadensis); COEI, Common Eider; GBBG, Greater Black-backed Gull (Larus marinus); GLGU, Glaucous Gull (Larus hyperboreus); goose spp., unspecified goose; HERG, American Herring Gull (Larus smithsonianus); NOPI, Northern Pintail (Anas acuta).

${ }^{\ddagger}$ Recurrent outbreak at the same location.

Fig. 2. Locations in the Hudson Strait region of the Canadian Arctic with confirmed, suspected, and unconfirmed (i.e., Inuitreported but not independently validated) Avian Cholera outbreaks.

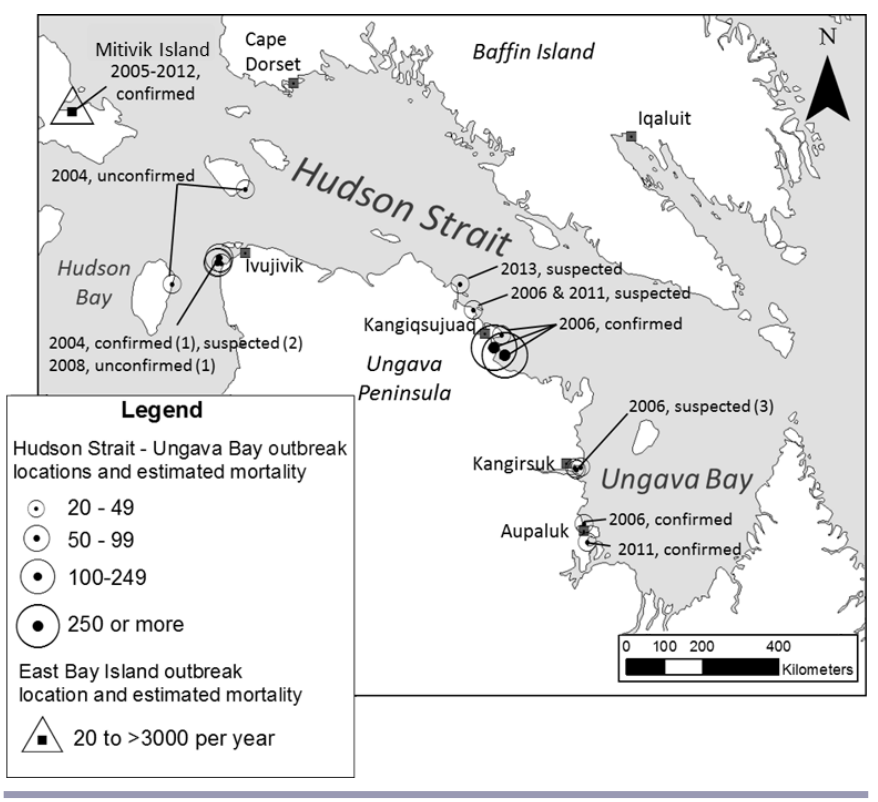

had been present. The remaining two outbreaks were detected by our research team during the course of its site surveys. A repeat outbreak was documented at one location, whereas the outbreaks at the other locations were confined to a single year (Table 2).

Inuit harvesters reported outbreaks at three additional locations that we were unable to investigate due to logistical constraints. These locations are mapped on Figure 2, but are not included in our quantitative analyses.

Geographically, the outbreaks clustered into three broad areas, all of which were on the southern coastline of the Hudson Strait (Fig. 2). Outbreaks were not identified on the northern coastline of the Hudson Strait (Baffin Island) despite extensive investigation and the presence of a similarly comprehensive network of Inuit harvesters.

The vast majority of carcasses reported by Inuit harvesters or observed during our surveys were Common Eiders $(N=1147$; Appendix 1, Figs. A1.1- A1.6). Percent mortality ranged from 1\% to $43 \%$ of the females estimated to use the nesting colonies. The largest outbreak in terms of total mortality included 309 dead Common Eiders, while the smallest included 21 dead Common Eiders (Table 2). Many fewer carcasses of Black Guillemots (Cepphus grylle; $N=9$ ), American Herring Gull $(N=6)$, and Glaucous Gulls $(N=3)$, as well as a single Greater Black-backed Gull (Larus marinus), a single Northern Pintail (Anas acuta), and a single Canada Goose (Branta canadensis) were discovered. 
Table 3. Model performance and goodness-of-fit results for category-specific and a cross-category composite model examining ecological predictors of Avian Cholera outbreak probability at Common Eider (Somateria mollissima) breeding colonies.

\begin{tabular}{|c|c|c|c|c|}
\hline & \multicolumn{2}{|c|}{$\begin{array}{l}\text { Area under receiver operating characteristic curve } \\
\text { (AUC) }\end{array}$} & \multicolumn{2}{|c|}{ Pearson jackknife test ${ }^{\dagger}$} \\
\hline & Training AUC & $\begin{array}{c}\text { Test } \\
\mathrm{AUC}( \pm \mathrm{SD})\end{array}$ & Success rate & $\mathrm{P}$ value \\
\hline $\begin{array}{c}\text { Category-specific models } \\
\text { Biophysical attributes } \\
\text { Focal host quantities } \\
\text { Disease dispersers }\end{array}$ & $\begin{array}{l}0.820 \\
0.807 \\
0.801\end{array}$ & $\begin{array}{l}0.767( \pm 0.169) \\
0.789( \pm 0.179) \\
0.741( \pm 0.137)\end{array}$ & $\begin{array}{l}85 \% \\
85 \% \\
78 \%\end{array}$ & $\begin{array}{l}0.003 \\
0.002 \\
0.006\end{array}$ \\
\hline $\begin{array}{l}\text { Cross-category model } \\
\qquad V E G+n C O E I+(P / 100 E)^{2}+C O E I-C F\end{array}$ & 0.856 & $0.830( \pm 0.113)$ & $92 \%$ & $<0.0001$ \\
\hline
\end{tabular}

${ }^{\top}$ There were 13 replicates with 12 training records and 1 test record in each run.

\section{Species-habitat model}

Model performance diagnostics indicated adequate goodness of fit on the basis of both AUC gain and $k$-fold jackknife validation for each of the category-specific models, as well as the crosscategory models, that we ran (Table 3 ).

Among the biophysical variables that we evaluated, the proportion of vegetation cover $(V E G)$ on islands had the greatest explanatory power (percent contribution $[\mathrm{PC}]=73.5$; permutation importance $[\mathrm{PI}]=85.1$; regression coefficient $[\beta \pm$ $\mathrm{SD}]: 2.66 \pm 0.22$ ). Model output indicated that the probability of an outbreak was positively correlated with the amount of vegetation on an island. Less support was apparent for the presence or number of ponds ( $p P O N D$ and $n P O N D$, respectively), and no difference in outbreak probability was apparent in relation to island size $(A R E A)$ or maximum elevation contour (ELEV; Table 4).

Within the focal host quantities category, estimates of parameter significance indicated support for the number of Common Eider nests $(n C O E I ; \mathrm{PC}=53.2 ; \mathrm{PI}=29.8 ; \beta \pm \mathrm{SD}: 1.96 \pm 0.37)$ and the number of ponds per 100 eider nests $\left[(P / 100 E)^{2} ; \mathrm{PC}=45.9\right.$; PI $=$ 69.7; $\beta \pm \mathrm{SD}: 1.75 \pm 0.55]$ as relevant explanatory variables. Comparatively little support was evident for the density of Common Eider nests ( $d C O E I$; Table 4).

Finally, within the disease disperser category, a strong correlation was apparent between outbreak probability and the degree of overlap between colony location and the intensity of flyway use by eiders moving into the Hudson Strait from wintering areas in Atlantic Canada (COEI-CF; PC $=66.1 ; \mathrm{PI}=74.3 .8 ; \beta \pm \mathrm{SD}: 1.96$ \pm 0.27 ; Fig. 3). Comparatively little support was apparent for a predictive relationship between outbreak probability and the presence or number of American Herring Gulls ( $p H E R G$, $n H E R G$ ), Glaucous Gulls ( $p G L G U, n G L G U$ ), or all gulls within a $5 \mathrm{~km}$ radius of an island $(a G U L L)$. Nor was there a significant correlation between outbreak probability and the degree of overlap between colony location and the breeding distributions or migration routes of Lesser Snow Geese (SNGO) or Common Eiders arriving in the Hudson Strait from wintering locations in Greenland (COEI-GF; Table 4).
Table 4. Best supported variables in category-specific analyses of Avian Cholera outbreak probability predictors at Common Eider (Somateria mollissima) breeding colonies.

\begin{tabular}{cccc}
\hline \hline Category & Variable & $\begin{array}{c}\text { Percent } \\
\text { contribution }\end{array}$ & $\begin{array}{c}\text { Permutation } \\
\text { importance }\end{array}$ \\
\hline Biophysical attributes & & \\
VEG & 73.5 & 85.1 \\
$p P O N D S$ & 20.0 & 2.3 \\
$n P O N D S$ & 4.3 & 11.4 \\
SIZE & 1.5 & 1.2 \\
ELEV & 0.7 & 0.1 \\
& & \\
Focal host quantities & & \\
$(P / 100 E)^{2}$ & 45.9 & 69.7 \\
$n C O E I$ & 53.2 & 29.8 \\
$d C O E I$ & 0.9 & 0.5 \\
& & \\
Disease dispersers & & 74.3 \\
COEI-CF & 66.1 & 13.0 \\
COEI-GF & 19.8 & 8.9 \\
$p H E R G$ & 9.5 & 2.7 \\
SNGO & 4.1 & 1.0 \\
$n G L G U$ & 0.2 & 0.0 \\
$p G L G U$ & 0.2 & 0.0 \\
$n H E R G$ & 0.1 & 0.0 \\
\hline$G U L L$ & 0.0 &
\end{tabular}

In the cross-category model, percent contribution to AUC gain was highest for $V E G$ and $C O E I-C F$, whereas permutation importance was highest for $V E G, C O E I-C F$, and $(P / 100 E)^{2}$ (Table 5). Marginal response curves indicate positive correlations between Avian Cholera outbreak probability and VEG, COEI$C F$, and $n C O E I$, whereas $(P / 100 E)^{2}$ followed a Poisson distribution, with peak outbreak probability occurring when ponds are present, but are relatively few in number (Fig. 4).

\section{DISCUSSION}

Our collaboration with Inuit harvesters revealed that Avian Cholera is much more widespread in the Canadian Arctic avifauna than previously described and that the distribution of outbreak events has been nonrandom within the study area with respect to ecological predictors. Although outbreaks have caused 
Fig. 3. Avian Cholera outbreak locations in relation to the migratory flyways of (a) Common Eiders (Somateria mollissima) wintering in Atlantic Canada, (b) Common Eiders wintering in Greenland, and (c) Lesser Snow Geese (Chen caerulescens caerulescens) wintering in the central United States. Stars indicate locations where outbreaks have been reported.
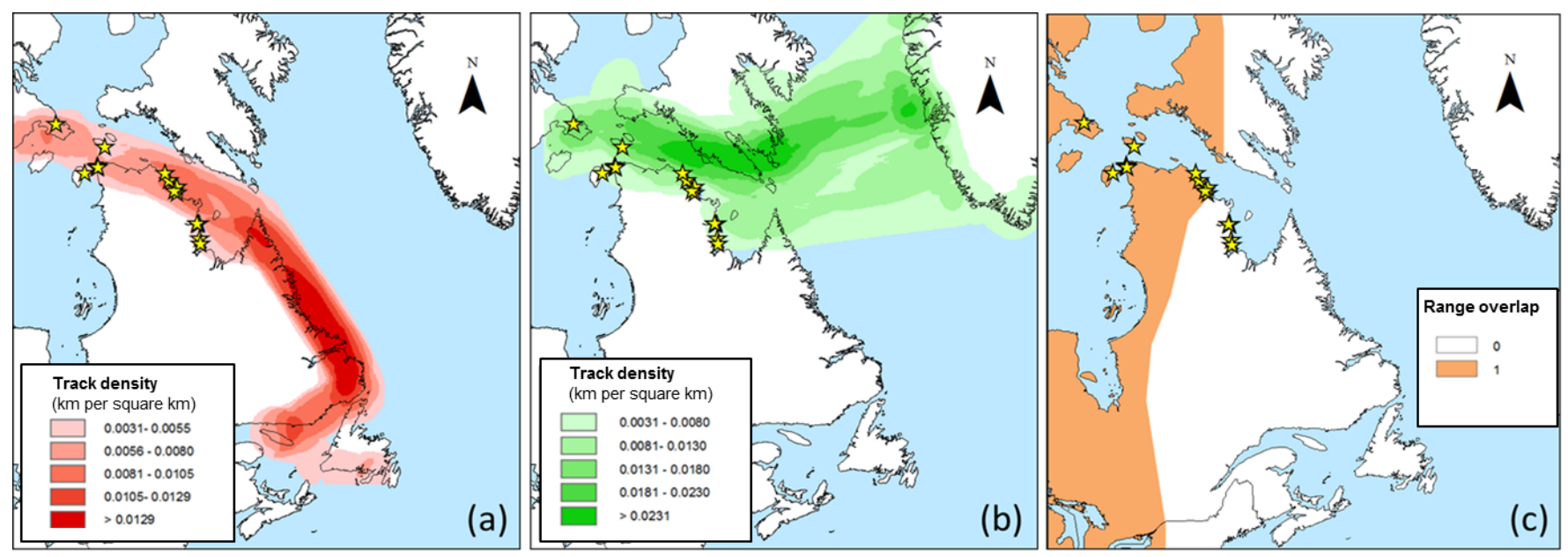

Table 5. Best supported variables in the cross-category analysis of Avian Cholera outbreak probability predictors at Common Eider (Somateria mollissima) breeding colonies.

\begin{tabular}{lccc}
\hline \hline Variable & $\begin{array}{c}\text { Percent } \\
\text { contribution }\end{array}$ & $\begin{array}{c}\text { Permutation } \\
\text { importance }\end{array}$ & $\begin{array}{c}\text { Model regression } \\
\text { coefficient }(\beta \pm \mathrm{SD})\end{array}$ \\
\hline$V E G$ & 40.1 & 35.4 & $1.53 \pm 0.27$ \\
$C O E I-C F$ & 35.7 & 27.2 & $2.83 \pm 1.18$ \\
$n C O E I$ & 13.0 & 11.1 & $1.65 \pm 0.27$ \\
$(P / 100 E)^{2}$ & 11.2 & 26.0 & $-17.01 \pm 5.96$ \\
\hline
\end{tabular}

high mortality at some locations, the outbreaks that we detected in the Hudson Strait have so far been localized and short in duration. This pattern stands in contrast to what has been observed at Mitivik Island, Nunavut (Descamps et al. 2012, Iverson et al. 2016), and several Common Eider breeding colonies in the St. Lawrence estuary of southern Québec, where recurrent outbreaks have been observed (The Joint Working Group on the Management of the Common Eider 2004). Moreover, outbreak occurrence has been temporally sporadic, suggesting that the pathogen is not readily maintained within the Northern Common Eider subpopulation across seasons, but rather requires periodic reintroduction to result in detectable outbreaks at breeding sites.

Perhaps the most significant finding of our study with respect to the current distribution of Avian Cholera in the Canadian Arctic is that outbreaks have been confined to the coastline of Ungava Peninsula and Ungava Bay. This finding potentially bears on the question of disease origins. Harms (2012) proposed two plausible explanations for the sudden appearance of Avian Cholera in Northern Common Eiders. The first is that a virulent strain of $P$. multocida jumped from American Common Eiders to Northern Common Eiders on shared wintering areas in Atlantic Canada during the nonbreeding season. The second is that the outbreaks originated from Lesser Snow Geese that winter in the central United States and come into contact with Northern Common Eiders during the breeding season. The spatial pattern of outbreaks that we observed is consistent with the former hypothesis, but not the latter. Eiders migrating into the Hudson Strait from Atlantic Canada closely follow the Ungava coastline, whereas the breeding and migration range of Lesser Snow Geese does not include the eastern portion of our study area, where many of the Avian Cholera outbreaks that we observed occurred. However, the preliminary results of molecular investigations into the phylogenetic relationships between $P$. multocida strains isolated from hosts in different areas do not indicate a close association between the bacterial subtype that has circulated in American

Fig. 4. Partial dependence plots showing the marginal response of Avian Cholera outbreak probability in relation to (a) percent vegetation cover, (b) migration track density of Common Eiders (Somateria mollissima) affiliated with wintering areas in Atlantic Canada, (c) number of Common Eider nests, and (d) the number of ponds per 100 eider nests (a measure of host crowding in shared wetlands).
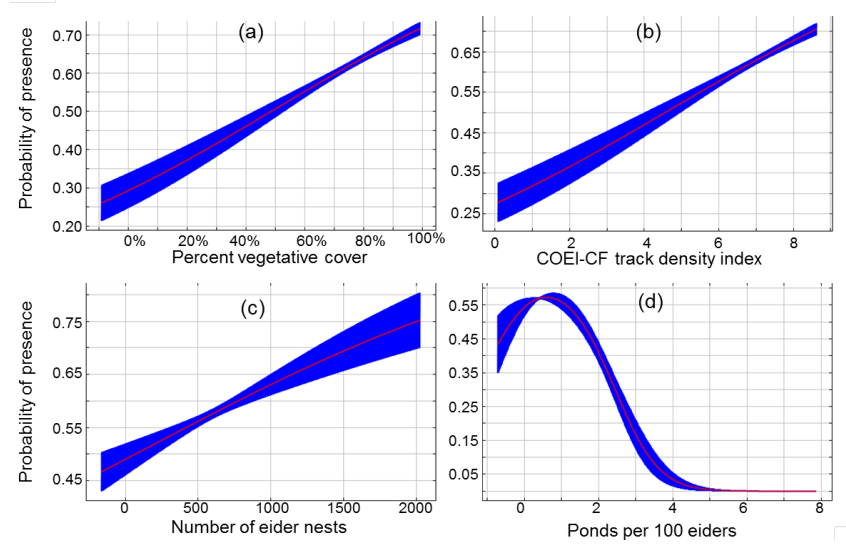
Common Eiders and the subtype isolated in Northern Common Eiders in the Hudson Strait (Harms 2015). Thus, although the results of this study strongly suggest the pathogen has circulated in the segment of the Northern Common Eider population that winters in Atlantic Canada, the original source of the pathogen does not appear to be American Common Eiders and remains a mystery.

A second issue to consider with respect to the nonrandom distribution of outbreak locations is the status of Avian Cholera as an emerging infectious disease in the Arctic ecosystem. The assumption of equilibrium between organisms and their environment is a standard postulate in most species-habitat models (Guisan and Thuiller 2005). However, this assumption is routinely violated in biological invasions, where spatial patterns of distribution are constrained by dispersal and the colonization processes (Václavík and Meentemeyer 2012). Within our study area, many locations with highly abundant eider colonies and biophysical attributes conducive to $P$. multocida transmission were not found to harbor disease. That the disease is present in some geographic segments of the eider population but not in others is consistent with a recent range expansion.

Given this caveat of recent range expansion, we still found percent vegetation cover in the terrestrial environment was the best supported predictor of outbreak probability. This result is somewhat surprising insofar as current research emphasizes the importance of contaminated wetlands as foci of P. multocida transmission in the wild (Samuel et al. 2004, Blanchong et al. 2006, Wobeser 2007). However, we found considerable variation in the presence and number of freshwater ponds among islands when assessing the habitat attributes of islands supporting colonies. Many of the islands that had ponds were depauperate in organic matter. Vegetation cover is likely a surrogate for a suite of factors relating to ground moisture retention and temperature, which are known to influence the survival of environmentally transmitted pathogens (Rohr and Raffel 2010, Wood et al. 2010), including P. multocida (Backstrand and Botzler 1986). It is likely that the association that we found between vegetation cover and outbreak probability encompasses a combination of sediment and pond characteristics not captured by pond presence and number alone.

Although the number of ponds on an island had little predictive value, the number of ponds available per nesting eider received considerable support as a predictor of outbreak probability. This predictiveness suggests that sharing terrestrial freshwater wetlands with many conspecifics led to the highest exposure to disease and is consistent with the hypothesis that higher infection risk is likely incurred as a cost of breeding (Botzler 1991, Descamps et al. 2009). Interestingly, we found more support for nesting eider abundance than for nesting density per se as a predictor of outbreak probability. We speculate that eider abundance is positively correlated with the probability of Avian Cholera introduction by carrier birds, whereas dense colonies did not necessarily have large numbers of eiders, nor did they necessarily have a scarcity of ponds. Together, these factors are a more relevant measure of host crowding and increased contact between birds and the pathogen in the environment.

Managing disease threats in Arctic wildlife is a major challenge. Ongoing interaction and information exchange among wildlife managers, disease specialists, and subsistence harvesters are a prerequisite for effective surveillance and devising workable control strategies (Kutz et al. 2009, Parlee et al. 2014). In temperate regions with a history of Avian Cholera occurrence, the primary focus of management has been the removal of carcasses from contaminated wetlands to reduce pathogen concentration in the environment (Wobeser 2007). Such action requires early detection and prompt response by trained individuals to ensure safe and effective disposal. An alternative approach, raised by Legagneux et al. (2014), is to actively encourage nesting birds to abandon their eggs at the first sign of Avian Cholera mortality and thereby induce movement away from affected locations. This tactic relies on the species tendency to return to the same nesting location each year (Goudie et al. 2000), in effect sacrificing current year productivity to decrease pathogen exposure and enhance adult survivorship. This too requires rapid intervention, but would be more logistically feasible within the vast geographic scope of the Arctic landscape and capacity of the local harvesters who benefit most from reducing Avian Cholera incidence. However, this strategy raises ethical issues with harvesters, who may be loath to actively haze animals to induce movement. Moreover, depending on the number of birds actively shedding virulent strains of $P$. multocida, induced migration could run the risk of spreading the disease further, to other locations.

It is also worth considering that disease mortality is a part of the ecology of host populations, and the available evidence suggests at least some Common Eiders infected by Avian Cholera survive and develop immunity (Korschgen et al. 1978, Iverson et al. 2016). As such, the short-term benefit of any management intervention designed to conserve abundance must be balanced against the possibility that efforts to reduce transmission are counterproductive if they only hinder natural selection for disease resistance (Staszewski and Boulinier 2004).

P. multocida infections pose little risk to human health (Christensen and Bisgaard 2000, Samuel et al. 2007); however, the Inuit harvesters with whom we collaborated indicated that they avoided outbreak sites following eider mass mortality events. Moreover, in the absence of a definitive diagnosis, public health authorities caution harvesters not to touch animals that are found dead. As such, enlisting local involvement in any effort involving mortality detection, sample collection for diagnostic purposes, or carcass removal will require education, training, and the provisioning of personal protective equipment. Our results suggest there is significant potential for the Avian Cholera epizootic to expand in the Canadian Arctic should the disease become entrenched in the Northern Common Eider population. We conclude that a community-based, participatory approach to disease surveillance and control stands the greatest chance of minimizing the population impact on eiders and other affected species, and the economic impact on eider feather down harvesters.

Responses to this article can be read online at: http://www.ecologyandsociety.org/issues/responses. $\mathrm{php} / 8873$ 


\section{Acknowledgments:}

Our research was funded by an NSERC Canada Strategic Projects Grant to M. R. Forbes and H. G. Gilchrist, Environment Canada's Strategic Applications of Genomics in the Environment (STAGE), Nunavut Wildlife Trust, Nunavut General Monitoring Program, Nunavik Marine Region Wildlife Board, ArcticNet, and the Canadian Wildlife Service of Environment Canada. We were assisted in the implementation of our field research by members of the Cape Dorset, Iqaluit, Kimmirut, Kangiqsujuaq, Aupaluk, Kangirsuk, and Ivujivik Hunters Fishers and Trappers associations. Laboratory analyses were coordinated and conducted by G. Seguin and A. Dallaire (CHWC-Québec) and N. J. Harms (CWHCWestern/Northern). Field work was carried out andlor facilitated by S. Suppa (Nunavik Research Centre), G. Donaldson, C. Paitre, and J. Akearok (Canadian Wildlife Service), and M. Travers, A. Black, J. Provencher, J. Brown, R. Dickson, M. Janssen, and J. Werner (Environment Canada, National Wildlife Research Centre). Helpful review comments were provided by T. Boulinier, T. Sherratt, G. Blouin-Demers, D. Henri, and J. van Dijk. S. Iverson was personally supported by academic scholarships from NSERC Canada, the W. Garfield Weston Foundation, and the Kenneth M. Molson Foundation.

\section{LITERATURE CITED}

Altizer, S., R. S. Ostfeld, P. T. Johnson, S. J. Kutz, and C. D. Harvell. 2013. Climate change and infectious diseases: from evidence to a predictive framework. Science 341:514-519. http:// dx.doi.org/10.1126/science.1239401

Arnal, A., M. Vittecoq, J. Pearce-Duvet, M. Gauthier-Clerc, T. Boulinier, and E. Jourdain. 2015. Laridae: A neglected reservoir that could play a major role in avian influenza virus epidemiological dynamics. Critical Reviews in Microbiology 41:508-519. http://dx.doi.org/10.3109/1040841X.2013.870967

Backstrand, J. M., and R. G. Botzler. 1986. Survival of Pasteurella multocida in soil and water in an area where avian cholera is enzootic. Journal of Wildlife Diseases 22:257-259. http://dx.doi. org/10.7589/0090-3558-22.2.257

Barry, S., and J. Elith. 2006. Error and uncertainty in habitat models. Journal of Applied Ecology 43:413-423. http://dx.doi. org/10.1111/j.1365-2664.2006.01136.X

Berkes, F. 2007. Community-based conservation in a globalized world. Proceedings of the National Academy of Sciences of the United States of America 104:15188-15193. http://dx.doi. org/10.1073/pnas.0702098104

Berkes, F., J. Colding, and C. Folke. 2000. Rediscovery of traditional ecological knowledge as adaptive management. Ecological Applications 10:1251-1262. http://dx.doi.org/10.1890/1051-0761 (2000)010[1251:ROTEKA]2.0.CO:2

Blanchong, J. A., M. D. Samuel, D. R. Goldberg, D. J. Shadduck, and M. A. Lehr. 2006. Persistence of Pasteurella multocida in wetlands following avian cholera outbreaks. Journal of Wildlife Diseases 42:33-39. http://dx.doi.org/10.7589/0090-3558-42.1.33

Bodenstein, B., K. Beckmen, G. Sheffield, K. Kuletz, C. Van Hemert, B. Berlowski, and V. Shearn-Bochsler. 2015. Avian cholera causes marine bird mortality in the Bering Sea of Alaska. Journal of Wildlife Diseases 51:934-937. http://dx.doi. org/10.7589/2014-12-273

Botzler, R. G. 1991. Epizootiology of avian cholera in wildfowl. Journal of Wildlife Diseases 27:367-395. http://dx.doi. org/10.7589/0090-3558-27.3.367

Brook, R. K., S. J. Kutz, A. M. Veitch, R. A. Popko, B. T. Elkin, and G. Guthrie. 2009. Fostering community-based wildlife health monitoring and research in the Canadian North. EcoHealth 6:266-278. http://dx.doi.org/10.1007/s10393-009-0256-7

Buttler, E. I., H. G. Gilchrist, S. Descamps, M. R. Forbes, and C. Soos. 2011. Handling stress of female Common Eiders during avian cholera outbreaks. Journal of Wildlife Management 75:283-288. http://dx.doi.org/10.1002/jwmg.38

Canadian Cooperative Wildlife Health Centre. 2007. Canadian Cooperative Wildlife Health Centre annual report 2006-2007. Canadian Cooperative Wildlife Health Centre: Newsletters \& Publications. [online] URL: http://digitalcommons.unl.edu/ icwdmccwhonews/49

Chapdelaine, G., A. Bourget, W. B. Kemp, D. J. Nakashima, and D. J. Murray. 1986. Population d'Eider à duvet près des côtes du Québec septentrional. Eider Ducks in Canada. Canadian Wildlife Service Report Series 47:39-50.

Christensen, J. P., and M. Bisgaard. 2000. Fowl cholera. Revue Scientifique et Technique 19:626-637. http://dx.doi.org/10.20506/ rst.19.2.1236

Christensen, T. K., T. Bregnballe, T. H. Andersen, and H. H. Dietz. 1997. Outbreak of Pasteurellosis among wintering and breeding Common Eiders Somateria mollissima in Denmark. Wildlife Biology 3:125-128.

Cooch, F. G. 1986. The number of nesting northern eiders on the West Foxe Islands, NWT, in 1956 and 1976, Eider Ducks in Canada. Canadian Wildlife Service Report Series 47:114-118.

Crawford, R. J. M., D. M. Allwright, and C. M. Heyl. 1992. High mortality of cape cormorants (Phalacrocorax capensis) off western South Africa in 1991 caused by Pasteurella multocida. Colonial Waterbirds 15:236-238. http://dx.doi.org/10.2307/1521458

Daszak, P., A. A. Cunningham, and A. D. Hyatt. 2001. Anthropogenic environmental change and the emergence of infectious diseases in wildlife. Acta Tropica 78:103-116. http://dx. doi.org/10.1016/S0001-706X(00)00179-0

Descamps, S., H. G. Gilchrist, J. Bêty, E. I. Buttler, and M. R. Forbes. 2009. Costs of reproduction in a long-lived bird: large clutch size is associated with low survival in the presence of a highly virulent disease. Biology Letters 5:278-281. http://dx.doi. org/10.1098/rsbl.2008.0704

Descamps, S., S. Jenouvrier, H. G. Gilchrist, and M. R. Forbes. 2012. Avian cholera, a threat to the viability of an Arctic seabird colony? PloS One 7(2):e29659. http://dx.doi.org/10.1371/journal. pone.0029659

Dobson, A. 2009. Climate variability, global change, immunity, and the dynamics of infectious diseases. Ecology 90:920-927. http://dx.doi.org/10.1890/08-0736.1 
Elith, J., S. J. Phillips, T. Hastie, M. Dudík, Y. E. Chee, and C. J. Yates. 2011. A statistical explanation of MaxEnt for ecologists. Diversity and Distributions 17:43-57. http://dx.doi.org/10.1111/ j.1472-4642.2010.00725.x

The Joint Working Group on the Management of the Common Eider. 2004. Québec management plan for the Common Eider Somateria mollissima dresseri. A special publication of the Joint Working Group on the Management of the Common Eider. Joint Working Group on the Management of the Common Eider, Québec, Canada. [online] URL: http://publications.gc.ca/ collections/collection 2014/ec/En154-24-2004-eng.pdf

Falardeau, G., J.-F. Rail, S. Gilliland, and J.-P. L. Savard. 2003. Breeding survey of common eiders along the west coast of Ungava Bay, in summer 2000, and a supplement on other nesting aquatic birds. Technical Report Series No. 405. Canadian Wildlife Service, Québec Region, Sainte-Foy, Canada.

Friend M. 1999. Avian cholera. Pages 75-92 in M. Friend and J. C. Franson, editors. Field manual of wildlife diseases: general field procedures and diseases of birds. U. S. Geological Survey, Madison, Wisconsin, USA.

Gaston, A., D. Cairns, and R. Elliot. 1985. A natural history of Digges Sound. Canadian Wildlife Service Report Series No. 46. Canadian Government Pub Centre, Ottawa, Ontario, Canada.

Gilchrist, G., and M. L. Mallory. 2007. Comparing expert-based science with local ecological knowledge: what are we afraid of? Ecology and Society 12(1):r1. [online] URL: http://www. ecologyandsociety.org/vol12/iss1/resp1

Gilchrist, G., M. Mallory, and F. Merkel. 2005. Can local ecological knowledge contribute to wildlife management? Case studies of migratory birds. Ecology and Society 10(1):20. [online] URL: http://www.ecologyandsociety.org/vol10/iss1/art20/

Goudie, R. I., G. J. Robertson, and A. Reed. 2000. Common Eider (Somateria mollissima). In A. Poole, editor. The birds of North America. Cornell Lab of Ornithology, Ithaca, New York, USA. [online] URL: http://bna.birds.cornell.edu/bna/species/546 http:// dx.doi.org/10.2173/bna.546

Guisan, A., and W. Thuiller. 2005. Predicting species distribution: offering more than simple habitat models. Ecology Letters 8:993-1009. http://dx.doi.org/10.1111/j.1461-0248.2005.00792.x

Harms, N. J. 2012. Exploring health and disease in northern Common Eiders in the Canadian Arctic. Arctic 65:495-499. http:// dx.doi.org/10.14430/arctic4255

Harms, N. J. 2015. Dynamics of disease: origins and ecology of avian cholera in the eastern Canadian Arctic. Dissertation. University of Saskatchewan, Saskatoon, Saskatchewan, Canada.

Harvell, C. D., C. E. Mitchell, J. R. Ward, S. Altizer, A. P. Dobson, R. S. Ostfeld, and M. D. Samuel. 2002. Climate warming and disease risks for terrestrial and marine biota. Science 296:2158-2162. http://dx.doi.org/10.1126/science.1063699

Harvell, D., S. Altizer, I. M. Cattadori, L. Harrington, and E. Weil. 2009. Climate change and wildlife diseases: when does the host matter the most? Ecology 90:912-920. http://dx.doi. org/10.1890/08-0616.1
Henri, D., H. G. Gilchrist, and E. Peacock. 2010. Understanding and managing wildlife in Hudson Bay under a changing climate: some recent contributions from Inuit and Cree ecological knowledge. Pages 267-289 in S. H. Ferguson, L. L. Loseto, and M. L. Mallory, editors. A little less Arctic. Springer, New York, New York, USA. http://dx.doi.org/10.1007/978-90-481-9121-5_13

Hipfner, J. M., H. G. Gilchrist, A. J. Gaston, and D. K. Cairns. 2002. Status of common eiders, Somateria mollissima, nesting in the Digges Sound region, Nunavut. Canadian Field-Naturalist 116:22-25.

Iverson, S. A., H. G. Gilchrist, C. Soos, I. I. Buttler, N. J. Harms, and M. R. Forbes. 2016. Injecting epidemiology into population viability analysis: avian cholera transmission dynamics at an arctic seabird colony. Journal of Animal Ecology. 85:1481-1490 http://dx.doi.org/10.1111/1365-2656.12585

Korschgen, C. E., H. C. Gibbs, and M. L. Mendall. 1978. Avian cholera in eider ducks in Maine. Journal of Wildlife Diseases 14:254-258. http://dx.doi.org/10.7589/0090-3558-14.2.254

Kowalchuk, K. A., and R. G. Kuhn. 2012. Mammal distribution in Nunavut: Inuit harvest data and COSEWIC's species at risk assessment process. Ecology and Society 17(3):4. http://dx.doi. org/10.5751/ES-04893-170304

Kutz, S. J., E. P. Hoberg, L. Polley, L., and E. J. Jenkins. 2005. Global warming is changing the dynamics of Arctic host-parasite systems. Proceedings of the Royal Society B: Biological Sciences 272:2571-2576. http://dx.doi.org/10.1098/rspb.2005.3285

Kutz, S. J., E. J. Jenkins, A. M. Veitch, J. Ducrocq, L. Polley, L., B. Elkin, and S. Lair. 2009. The Arctic as a model for anticipating, preventing, and mitigating climate change impacts on hostparasite interactions. Veterinary Parasitology 163:217-228. http:// dx.doi.org/10.1016/j.vetpar.2009.06.008

Kwan, M. 2004. Avian cholera outbreak in Ivujivik. Makvik Magazine 70:1-32.

Legagneux, P., L. L. Berzins, M. R. Forbes, N. J. Harms, H. L. Hennin, S. Bourgeon, H. G. Gilchrist, J. Bêty, C. Soos, O. P. Love, J. T. Foster, S. Descamps, and G. Burness. 2014. No selection on immunological markers in response to a highly virulent pathogen in an Arctic breeding bird. Evolutionary Applications 7:765-773. http://dx.doi.org/10.1111/eva.12180

Liu, X., J. R. Rohr, and Y. Li. 2013. Climate, vegetation, introduced hosts and trade shape a global wildlife pandemic. Proceedings of the Royal Society B: Biological Sciences 280:20122506. http://dx.doi.org/10.1098/rspb.2012.2506

Love, O. P., H. G. Gilchrist, S. Descamps, C. A. D. Semeniuk, and J. Bêty. 2010. Pre-laying climatic cues can time reproduction to optimally match offspring hatching and ice conditions in an Arctic marine bird. Oecologia 164:277-286. http://dx.doi. org/10.1007/s00442-010-1678-1

Mallory, M. L., H. G. Gilchrist, A. J. Fontaine, and J. A. Akearok. 2003. Local ecological knowledge of ivory gull declines in Arctic Canada. Arctic 56:293-298. http://dx.doi.org/10.14430/arctic625

Mosbech, A., H. G. Gilchrist, F. Merkel, C. Sonne, A. Flagstad, and H. Nyegaard. 2006. Year-round movements of northern 
Common Eiders Somateria mollissima borealis breeding in Arctic Canada and West Greenland followed by satellite telemetry. Ardea 94:651-665.

Mweya, C. N., S. I. Kimera, J. Bukombe, and L. E. B. Mboera. 2013. Predicting distribution of Aedes aegypti and Culex pipiens complex, potential vectors of Rift Valley fever virus in relation to disease epidemics in East Africa. Infection Ecology \& Epidemiology, volume 3. http://dx.doi.org/10.3402/iee.v3i0.21748

Nakashima, D. J. 1991. The ecological knowledge of Belcher Island Inuit: a traditional basis for contemporary wildlife co-management. Dissertation. McGill University, Montreal, Québec, Canada.

Österblom, H., H. P. Van Der Jeugd, and O. Olsson, O. 2004. Adult survival and avian cholera in common guillemots Uria aalge in the Baltic Sea. Ibis 146:531-534. http://dx.doi.org/10.1111/ j.1474-919X.2004.00266.X

Parlee, B. L., E. Goddard., Ł. K. D. First Nation, and M. Smith. 2014. Tracking change: traditional knowledge and monitoring of wildlife health in Northern Canada. Human Dimensions of Wildlife 19:47-61. http://dx.doi.org/10.1080/10871209.2013.825823

Pearson, R. G., C. J. Raxworthy, M. Nakamura, and A. T. Peterson. 2007. Predicting species distributions from small numbers of occurrence records: a test case using cryptic geckos in Madagascar. Journal of Biogeography 34:102-117. http://dx. doi.org/10.1111/j.1365-2699.2006.01594.x

Phillips, S. J., R. P. Anderson, and R. E. Schapire. 2006. Maximum entropy modeling of species geographic distributions. Ecological Modelling 190:231-259. http://dx.doi.org/10.1016/j.ecolmodel.2005.03.026

Plowright, R. K., S. H. Sokolow, M. E. Gorman, P. Daszak, and J. E. Foley. 2008. Causal inference in disease ecology: investigating ecological drivers of disease emergence. Frontiers in Ecology and the Environment 6:420-429. http://dx.doi.org/10.1890/070086

Reed, A., and J.-G. Cousineau. 1967. Epidemics involving the common eider (Somateria mollissima) at Ile Blanche, Québec. Le Naturaliste Canadien 94:327-334.

Robertson, G. J., and H. G. Gilchrist. 1998. Evidence of population declines among Common Eiders breeding in the Belcher Islands, Northwest Territories. Arctic 51:378-385. http:// dx.doi.org/10.14430/arctic1081

Rohr, J. R., and T. R. Raffel, T. R. 2010. Linking global climate and temperature variability to widespread amphibian declines putatively caused by disease. Proceedings of the National Academy of Sciences of the United States of America 107:8269-8274. http:// dx.doi.org/10.1073/pnas.0912883107

Samuel, M. D., R. G. Botzler, and G. A. Wobeser. 2007. Avian cholera. Pages 239-269 in N. J. Thomas, D. B. Hunter, and C. T. Atkinson, editors. Infectious diseases of wild birds. Blackwell Publishing Professional, Ames, Iowa, USA. http://dx.doi. org/10.1002/9780470344668.ch12

Samuel, M. D., D. J. Shadduck, and D. R. Goldberg. 2004. Are wetlands the reservoir for avian cholera? Journal of Wildlife Diseases 40:377-382. http://dx.doi.org/10.7589/0090-3558-40.3.377

Samuel, M. D., D. J. Shadduck, D. R. Goldberg, and W. P. Johnson. 2005. Avian cholera in waterfowl: the role of lesser snow and Ross's geese as disease carriers in the Playa Lakes Region. Journal of Wildlife Diseases 41:48-57. http://dx.doi. org/10.7589/0090-3558-41.1.48

Savard, J.-P. L., L. Lesage, S. G. Gilliland, H. G. Gilchrist, and J.-F. Giroux. 2011. Molting, staging, and wintering locations of Common Eiders breeding in the Gyrfalcon Archipelago, Ungava Bay. Arctic 64:197-206. http://dx.doi.org/10.14430/arctic4099

Skarphédinsson, K. H. 1996. The Common Eider-some ecological and economical aspects. Bulletin of the Scandinavian Society for Parasitology 6:90-97.

Slater, H., and E. Michael. 2012. Predicting the current and future potential distributions of lymphatic filariasis in Africa using maximum entropy ecological niche modelling. PloS One 7(2): e32202. http://dx.doi.org/10.1371/journal.pone.0032202

Smith, D. L., B. Lucey, L. A. Waller, J. E. Childs, and L. A. Real. 2002. Predicting the spatial dynamics of rabies epidemics on heterogeneous landscapes. Proceedings of the National Academy of Sciences of the United States of America 99:3668-3672. http:// dx.doi.org/10.1073/pnas.042400799

Staszewski, V., and T. Boulinier. 2004. Vaccination: a way to address questions in behavioral and population ecology? Trends in Parasitology 20:17-22. http://dx.doi.org/10.1016/j.pt.2003.11.005

Swennen, C., and T. Smit. 1991. Pasteurellosis among breeding eiders Somateria mollissima in the Netherlands. Wildfowl 42:94-97.

U.S. Fish and Wildlife Service. 2007. Final environmental impact statement-light goose management. U.S. Fish and Wildlife Service, Washington, D.C., USA.

Václavík, T., and R. K. Meentemeyer. 2012. Equilibrium or not? Modelling potential distribution of invasive species in different stages of invasion. Diversity and Distributions 18:73-83. http://dx. doi.org/10.1111/j.1472-4642.2011.00854.X

Waller, L. J., and L. G. Underhill. 2007. Management of avian cholera Pasteurella multocida outbreaks on Dyer Island, South Africa, 2002-2005. African Journal of Marine Science 29:105-111. http://dx.doi.org/10.2989/AJMS.2007.29.1.9.74

Wille, M., S. C. McBurney, G. J. Robertson, S. I. Wilhelm, D. S. Blehert, C. S. Soos, R. Dunphy, and H. Whitney. 2016. A pelagic outbreak of Avian Cholera in North American gulls: scavenging as a primary mechanism for transmission? Journal of Wildlife Diseases 52:793-802. http://dx.doi.org/10.7589/2015-12-342

Wobeser, G. A. 2007. Disease in wild animals: investigation and management. Second edition. Springer-Verlag, Berlin, Germany. http://dx.doi.org/10.1007/978-3-540-48978-8

Wood, J. P., Y. W. Choi, D. J. Chappie, J. V. Rogers, and J. Z. Kaye. 2010. Environmental persistence of a highly pathogenic avian influenza (H5N1) virus. Environmental Science and Technology 44:7515-7520. http://dx.doi.org/10.1021/es1016153 


\section{Appendix 1. Additional details concerning survey locations}

Here we describe locational details of common eider colonies surveyed in the Hudson Strait Region of the Canadian Arctic.

Nearly all of the islands that we surveyed were within study areas previously delineated and surveyed by Canadian Wildlife Service biologists (Gaston et al. 1985, Chapdelaine et al. 1986, Cooch 1986, Hipfner et al. 2002, Falardeau et al. 2003, H. G. Gilchrist and J. Akearok, Environment Canada, unpublished data). These historical surveys prioritized monitoring trends in abundance on islands identified as suitable habitat for nesting eiders $\left(<2 \mathrm{~km}^{2}\right.$ in area; $0.5-10 \mathrm{~km}$ from nearest mainland shore; elevation $<50 \mathrm{~m}$ ) (Robertson and Gilchrist 1998, Falardeau et al. 2003).

Site selection protocols differed among the teams initially implementing the research. In some zones, site selection was based on random draws of islands deemed to have suitable habitat (survey zones 1-3, 7 and 9-10), while in other areas even more comprehensive sampling was undertaken wherein $>80 \%$ of suitable islands within pre-defined study areas were surveyed (survey zones 4-6, 8 and 11-13).

For each survey zone, the summary information including the nearest community, the number of colonies investigated which had $\geq 20$ nesting pairs of eiders, and the year that we visited the island are provided in Table A1.1. Survey zones in the vicinity of Cape Dorset were visited on multiple occasions as part of a long-term population monitoring program. Survey zones in the vicinity of other locations were visited on a single occasion only.

Georeferenced coordinates of outbreak sites are are provided in Table A1.2 and accompany survey zone specific maps presented in Figures A1.1 to A1.13.

Table A1.1. Sampling effort summarized by survey zone. Survey zone number and name correspond to areas identified in Figure 1. Number of colonies refers to the number of Northern Common Eider colonies with $\geq 20$ nesting pairs identified within each zone. Original source for survey locations refers to documentation by Canadian Wildlife Service of past survey effort.

\begin{tabular}{|c|c|c|c|c|}
\hline $\begin{array}{l}\text { Nearest } \\
\text { community }\end{array}$ & $\begin{array}{l}\text { Survey zone number } \\
\text { and name }\end{array}$ & $\begin{array}{l}\text { Number of } \\
\text { colonies }\end{array}$ & $\begin{array}{l}\text { Year(s) of } \\
\text { survey }\end{array}$ & Original source for survey locations \\
\hline Aupaluk & 1 1 - Ikkatuk Bay & 9 & 2011 & Chapdelaine et al. 1986; Falardeau et al. 2003 \\
\hline \multirow[t]{2}{*}{ Kangirsuk } & 2 - Payne Bay & 9 & 2012 & Chapdelaine et al. 1986; Falardeau et al. 2003 \\
\hline & 3 - Plover Bay & 9 & 2012 & Chapdelaine et al. 1986; Falardeau et al. 2003 \\
\hline \multirow[t]{2}{*}{ Kangiqsujuaq } & 4 - Joy Bay & 6 & 2011 & Not previously surveyed \\
\hline & 5 - King George Sound & 9 & 2011 & Not previously surveyed \\
\hline Ivujivik & 6 - Digges Sound & 15 & 2012 & Gaston et al. 1985, Hipfner et al. 2002 \\
\hline \multirow[t]{4}{*}{ Cape Dorset } & 7 - Foxe Peninsula & 8 & 2010 & $\begin{array}{l}\text { G. Gilchrist, Environment Canada, unpubl. } \\
\text { data }\end{array}$ \\
\hline & 8 - West Foxe Islands & 15 & $\begin{array}{l}2010, \\
2011, \\
2012\end{array}$ & Cooch 1986; \\
\hline & 9 - Chorkbak Inlet & 24 & 2010 & $\begin{array}{l}\text { G. Gilchrist, Environment Canada, unpubl. } \\
\text { data }\end{array}$ \\
\hline & $\begin{array}{l}10 \text { - Chamberlain } \\
\text { Islands }\end{array}$ & 19 & $\begin{array}{l}2010, \\
2011, \\
2012\end{array}$ & $\begin{array}{l}\text { G. Gilchrist, Environment Canada, unpubl. } \\
\text { data }\end{array}$ \\
\hline \multirow[t]{2}{*}{ Iqaluit } & $\begin{array}{l}11 \text { - Frobisher Bay } \\
\text { North }\end{array}$ & 1 & 2013 & J. Akearok, Environment Canada, unpubl. data \\
\hline & 12 - Frobisher Bay & 4 & 2013 & J. Akearok, Environment Canada, unpubl. data \\
\hline
\end{tabular}




\section{Appendix 1. Additional details concerning survey locations}

\begin{tabular}{|c|c|c|c|c|}
\hline & $\begin{array}{l}\text { Central } \\
13 \text { - Frobisher Bay } \\
\text { South }\end{array}$ & 3 & 2013 & J. Akearok, Environment Canada, unpubl. data \\
\hline Total & All & 131 & & \\
\hline
\end{tabular}

Table A1.2. Location of Avian Cholera outbreaks occurring on Northern Common Eider colonies in the Hudson Strait region of the Canadian Arctic between 2004 and 2013. Survey zone number and name correspond to areas identified in Figure 1. Outbreak identification number corresponds to mapped identification numbers provided in Figures A1.1 - A1.13. Outbreak identification numbers 13a and 13b refer to outbreaks occurring in multiple years at the same location.

\begin{tabular}{|c|c|c|c|}
\hline $\begin{array}{l}\text { Outbreak } \\
\text { identification } \\
\text { number }\end{array}$ & $\begin{array}{l}\text { Outbreak } \\
\text { year }\end{array}$ & Survey zone number and name & Longitude, Latitude \\
\hline 1 & 2004 & 6 - Digges Sound & $-78.185,62.384$ \\
\hline 2 & 2004 & 6 - Digges Sound & $-78.171,62.431$ \\
\hline 3 & 2004 & 6 - Digges Sound & $-78.204,62.377$ \\
\hline $4^{\dagger}$ & 2004 & Mansel Island (not surveyed) & $-79.266,62.137$ \\
\hline $5^{\dagger}$ & 2004 & Nottingham Island (not surveyed) & $-77.537,63.167$ \\
\hline 6 & 2006 & 1- Ikkatuk Bay & $-69.548,59.378$ \\
\hline 7 & 2006 & 2 - Payne Bay & $-69.620,60.048$ \\
\hline 8 & 2006 & 2- Payne Bay & $-69.710,60.015$ \\
\hline 9 & 2006 & 2 - Payne Bay & $-69.751,60.036$ \\
\hline 10 & 2006 & 4 - Joy Bay & $-71.440,61.332$ \\
\hline 11 & 2006 & 4 - Joy Bay & $-71.477,61.569$ \\
\hline 12 & 2006 & 4 - Joy Bay & $-71.702,61.419$ \\
\hline $13 \mathrm{a}$ & 2006 & 5 - King George Sound & $-72.155,61.847$ \\
\hline $13 b$ & 2006 & 5 - King George Sound & $-72.155,61.847$ \\
\hline $14^{\dagger}$ & 2008 & 6- Digges Sound & $-78.109,62.367$ \\
\hline 15 & 2011 & 1 - Ikkatuk Bay & $-69.466,59.155$ \\
\hline 16 & 2013 & 5 - King George Sound & $-72.463,62.132$ \\
\hline
\end{tabular}

${ }^{\dagger}$ Locations excluded from the MAXENT species distribution model analysis because site investigation documenting avian mortality and site attributes was not undertaken by Environment Canada biologists. 
Appendix 1. Additional details concerning survey locations

Figure A1.1 Survey zone 1: Ikkatuk Bay, Western Ungava Bay

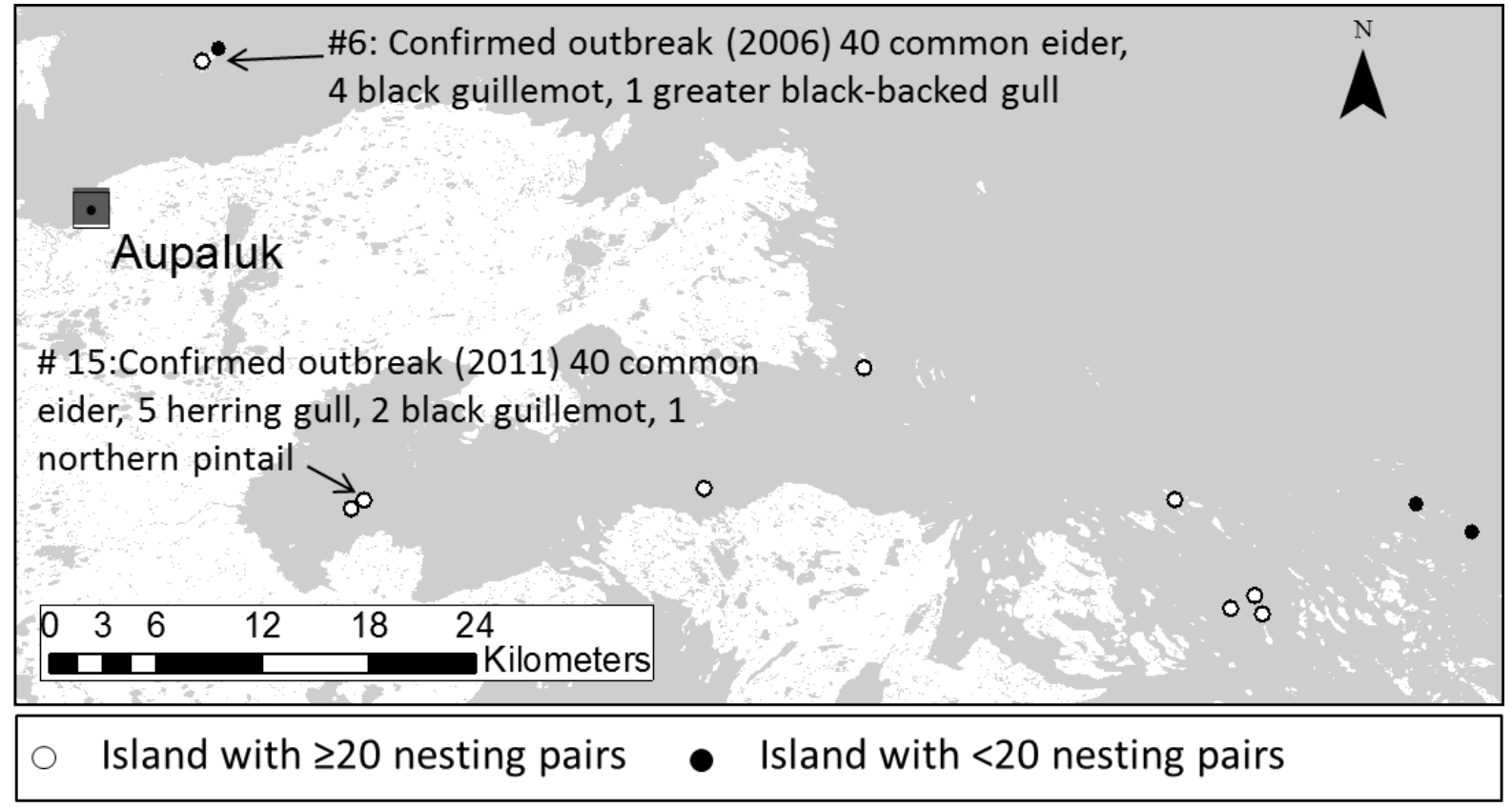

Figure A1.2. Survey zone 2: Payne Bay, Western Ungava Bay

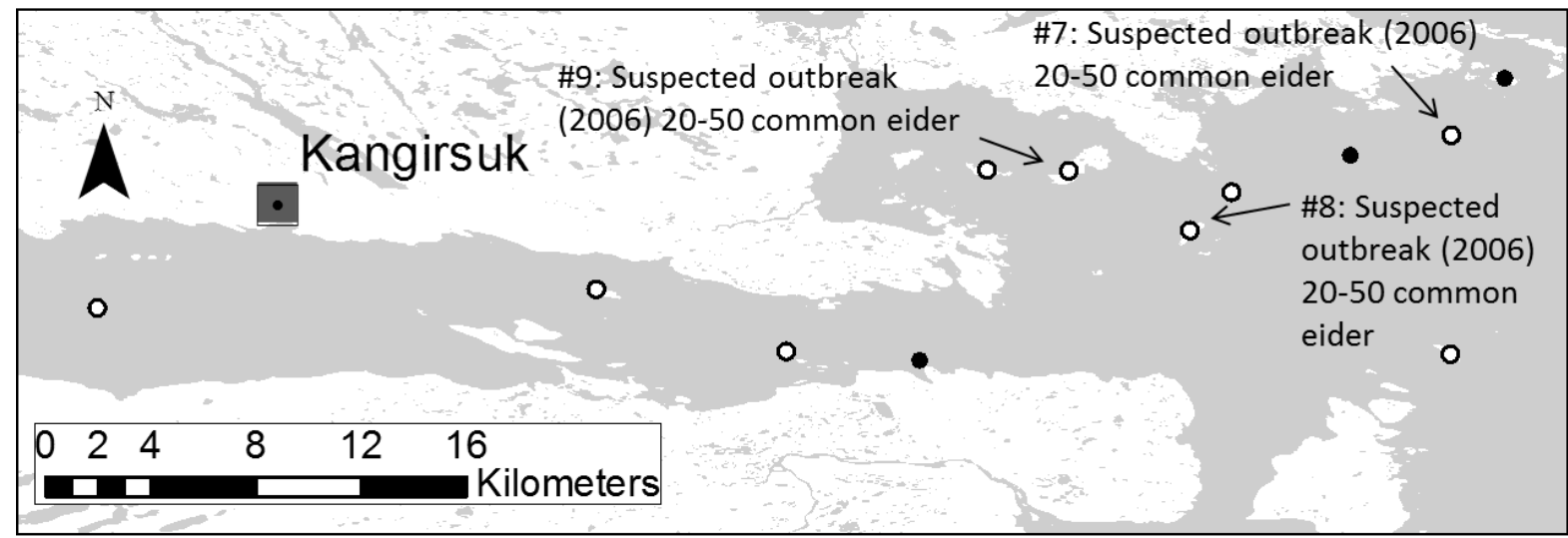

Island with $\geq 20$ nesting pairs

- Island with $<20$ nesting pairs 
Appendix 1. Additional details concerning survey locations

Figure A1.3. Survey zone 3: Plover Islands, Western Ungava Bay

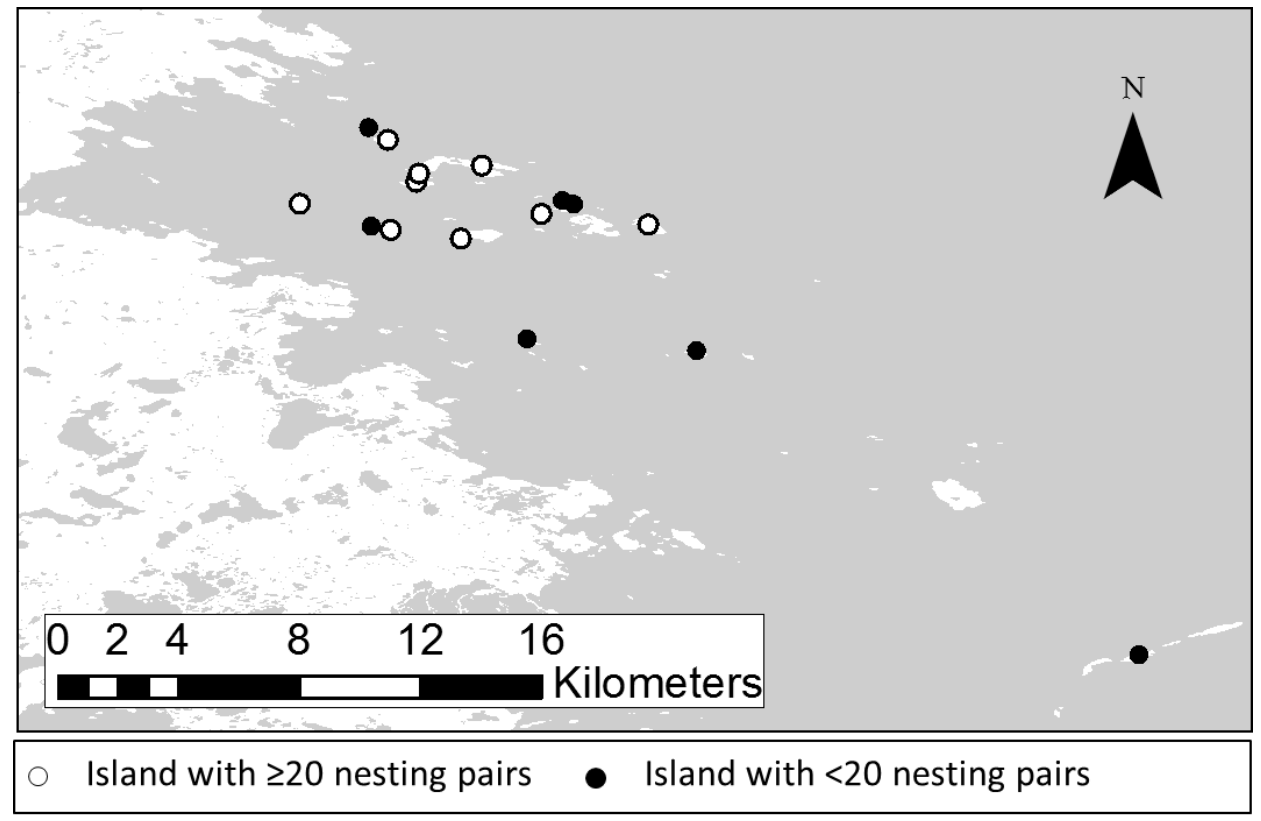

Figure A1.4. Survey zone 4: Joy Bay, Central Ungava Peninsula

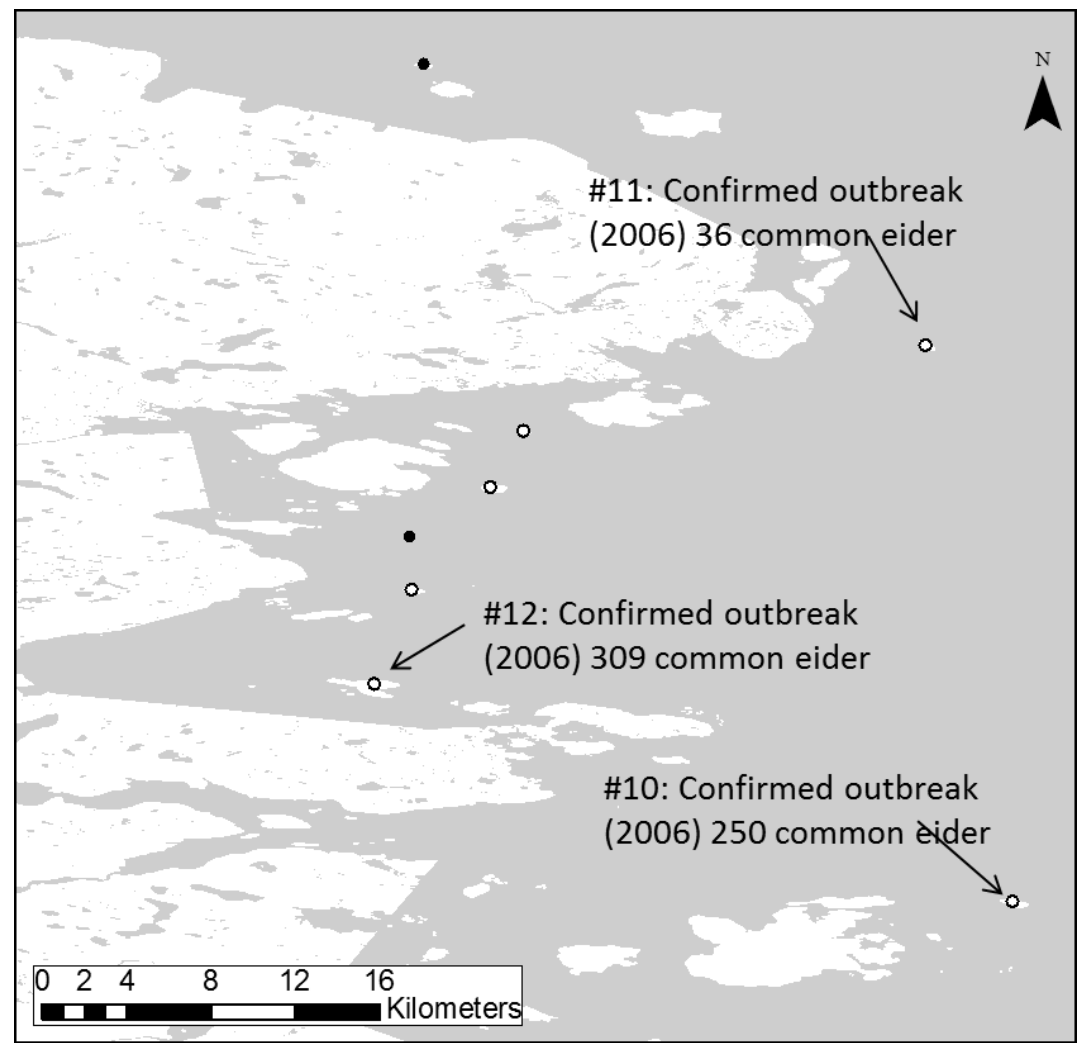

0 Island with $\geq 20$ nesting pairs $\bullet$ Island with $<20$ nesting pairs 


\section{Appendix 1. Additional details concerning survey locations}

Figure A1.5. Survey zone 5: King George Sound, Central Ungava Peninsula

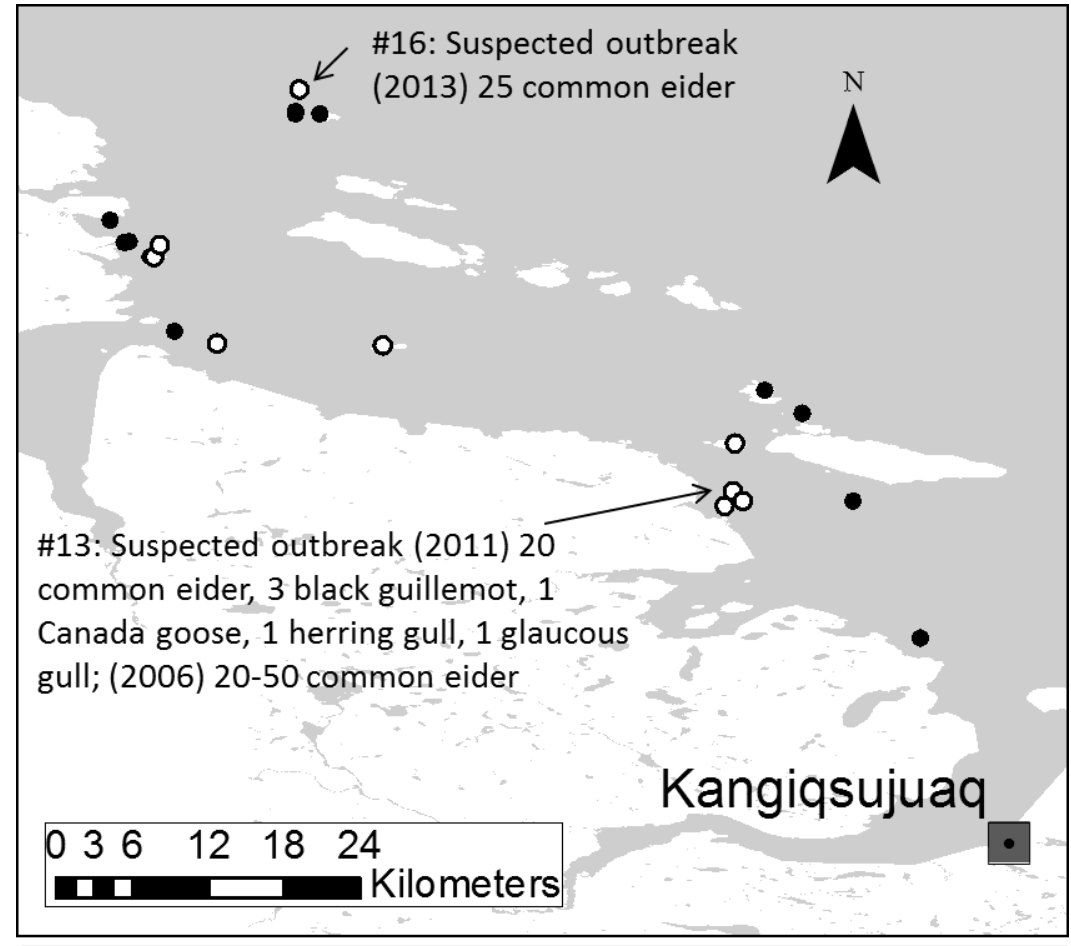

Island with $\geq 20$ nesting pairs

Island with $<20$ nesting pairs

Figure A1.6. Survey zone 6: Digges Sound

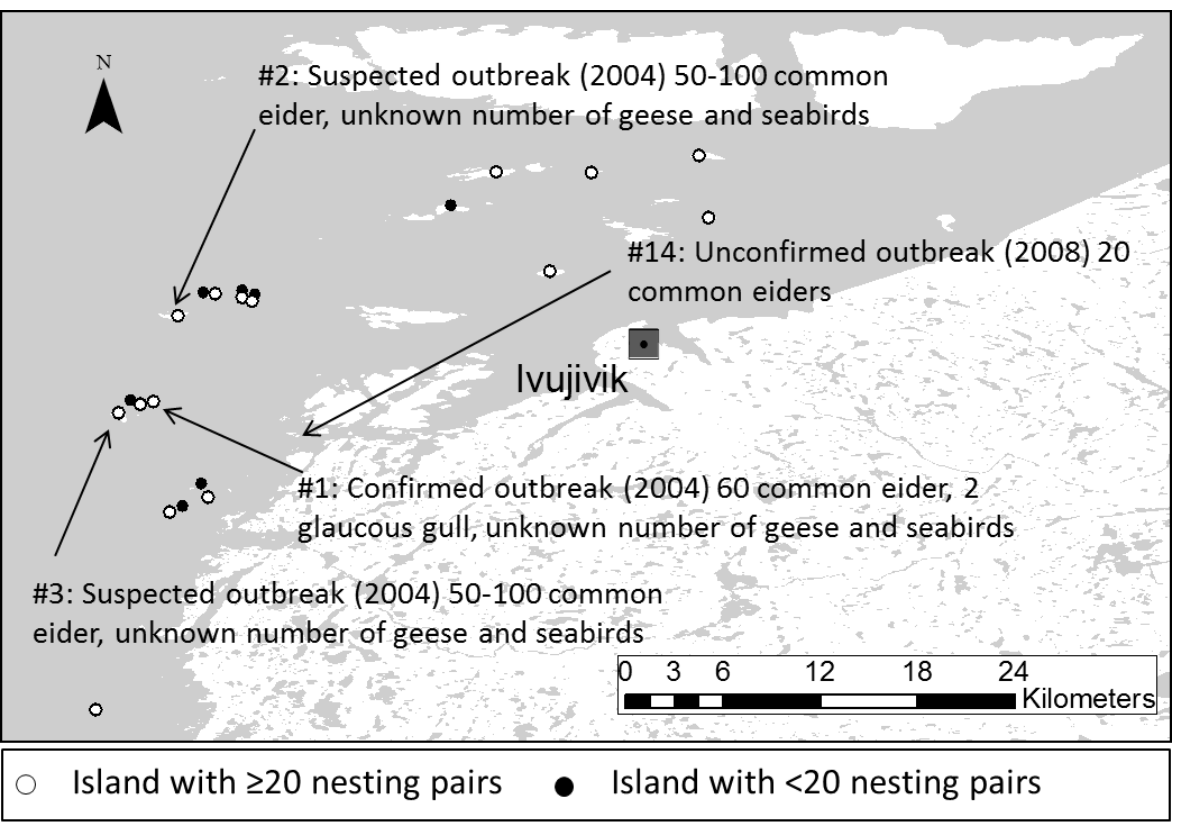


Appendix 1. Additional details concerning survey locations

Figure A1.7. Survey zone 7: Foxe Peninsula, Southern Baffin Island

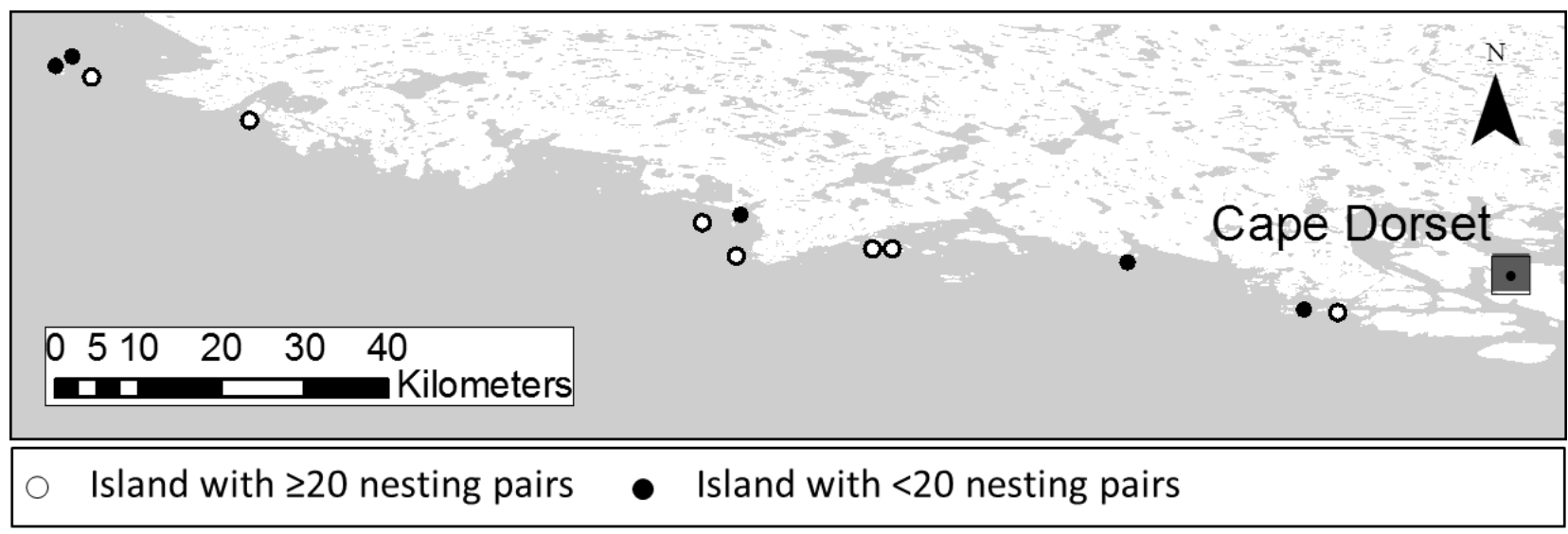

Figure A.8. Survey zone 8: West Foxe Islands, Southern Baffin Island

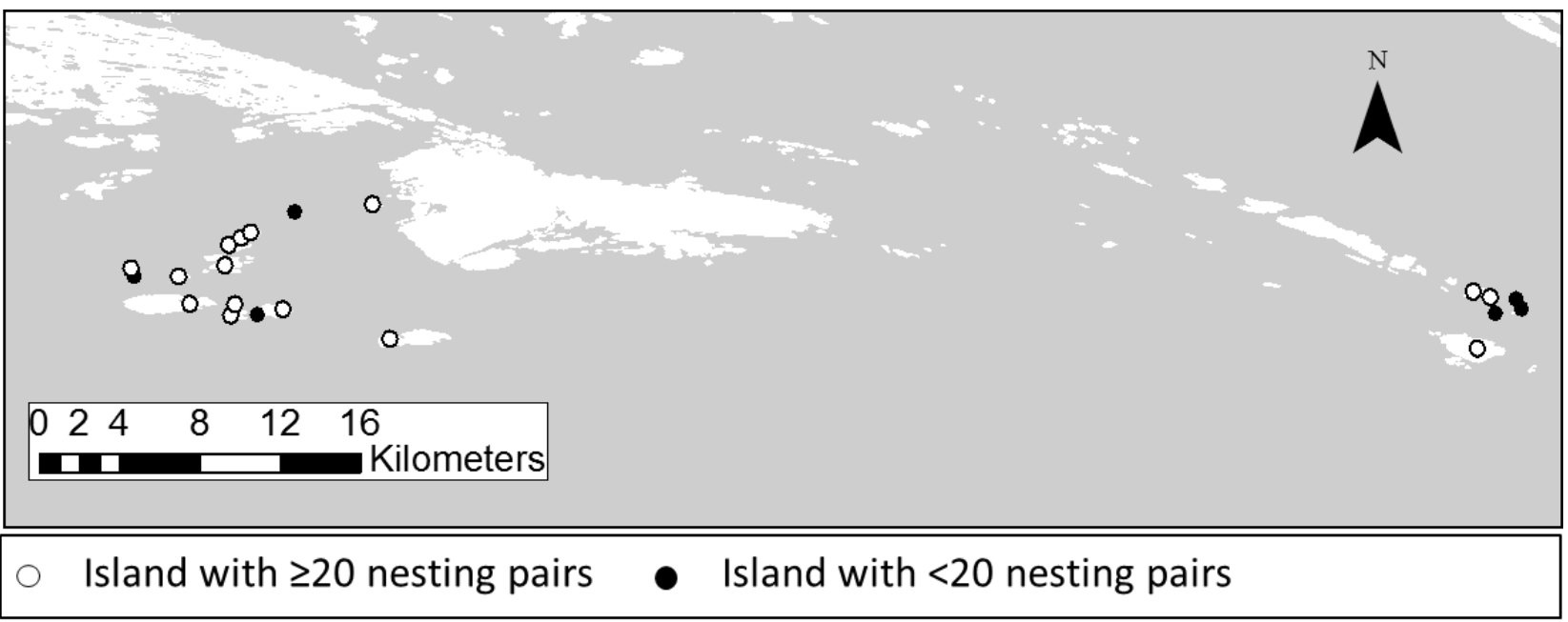


Appendix 1. Additional details concerning survey locations

Figure A1.9. Survey zone 9: Chorkbak Inlet, Southern Baffin Island

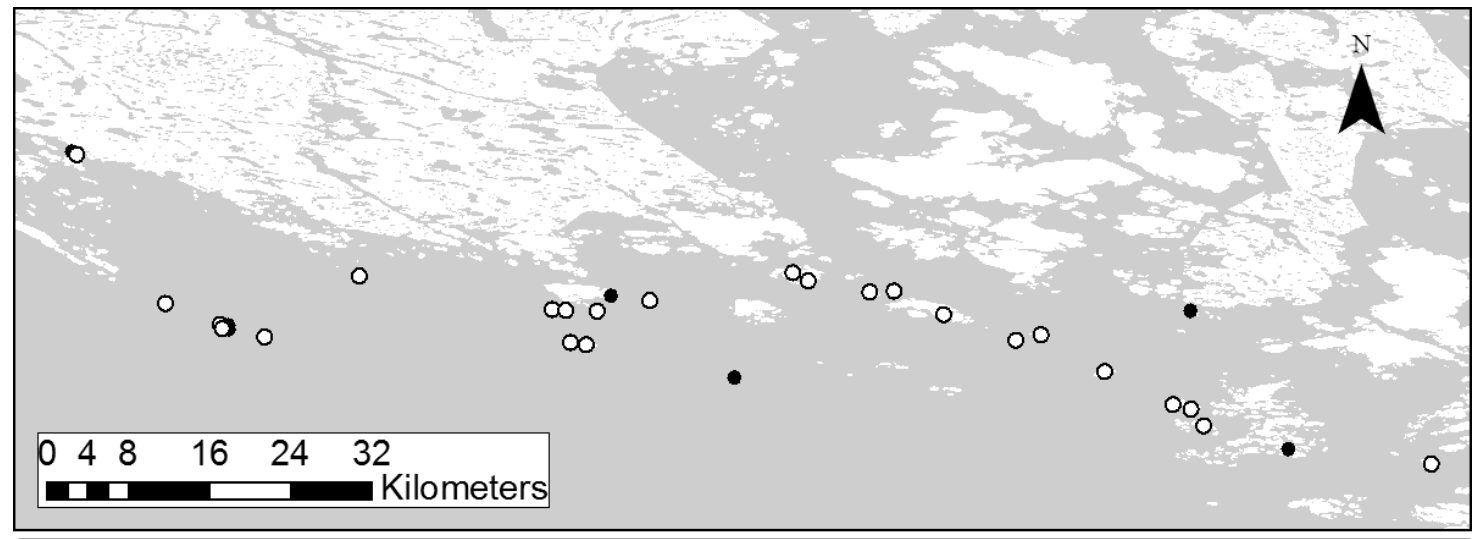

$\circ$ Island with $\geq 20$ nesting pairs

Island with $<20$ nesting pairs

Figure A1.10. Survey zone 10: Chamberlain Islands, Southern Baffin Island

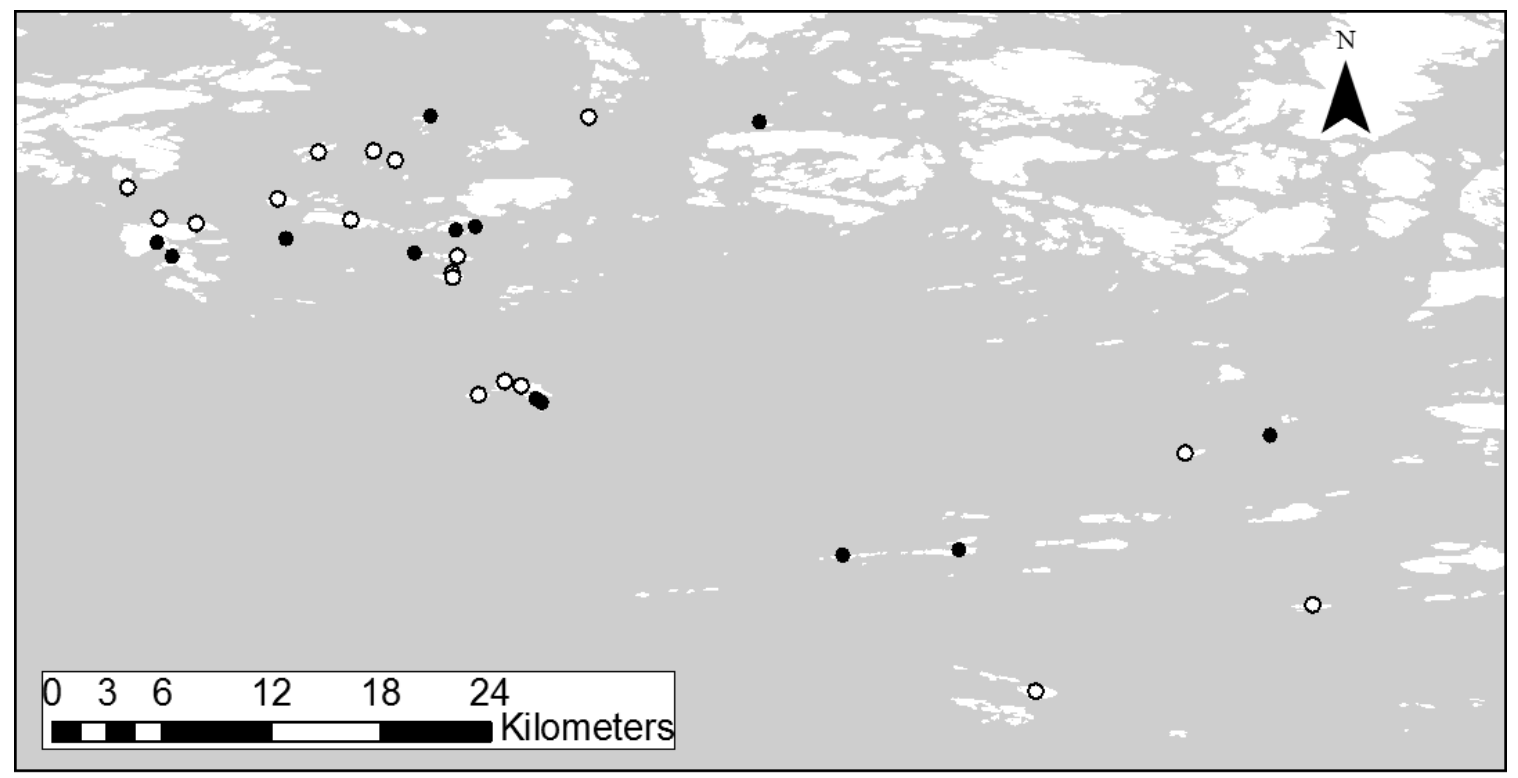

$\bigcirc$ Island with $\geq 20$ nesting pairs $\bullet$ Island with $<20$ nesting pairs 
Appendix 1. Additional details concerning survey locations

Figure A1.11. Survey zone 11: Northern Frobisher Bay, Frobisher Bay

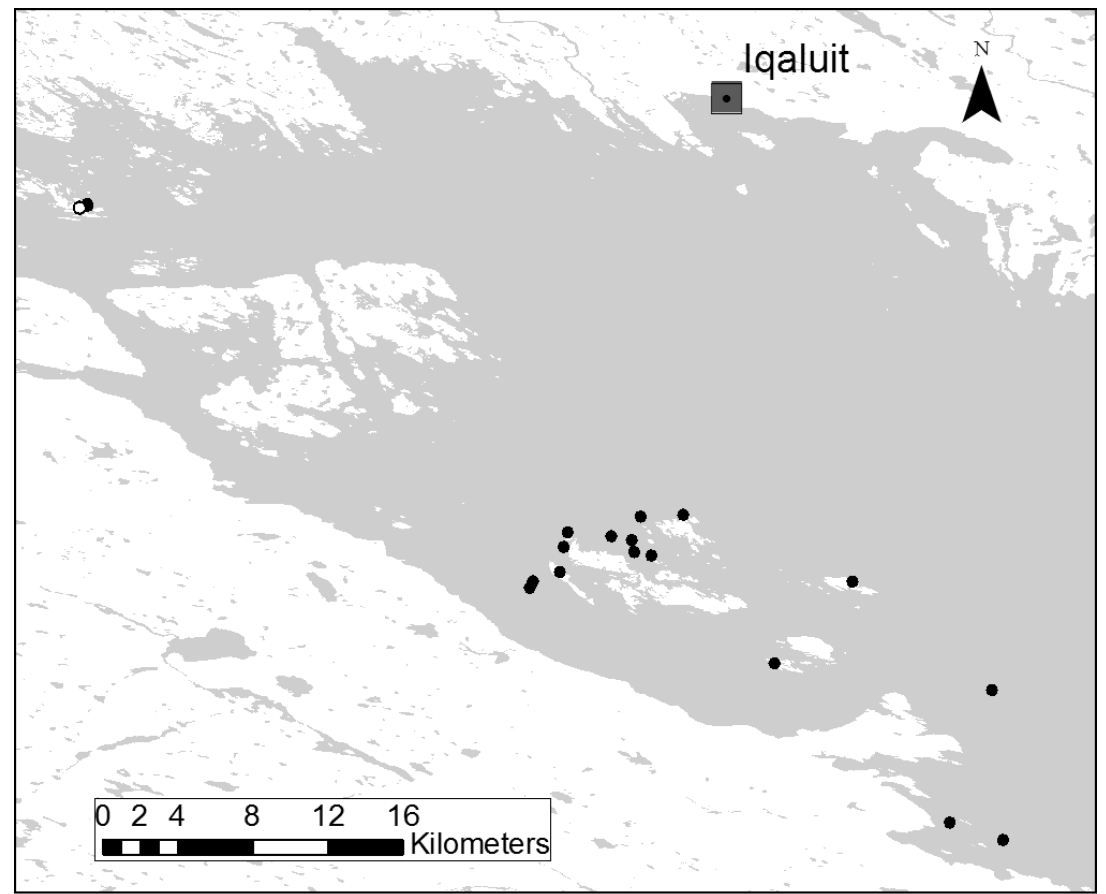

0 Island with $\geq 20$ nesting pairs $\bullet$ Island with $<20$ nesting pairs

Figure A2.12. Survey zone 12: Central Frobisher Bay, Frobisher Bay

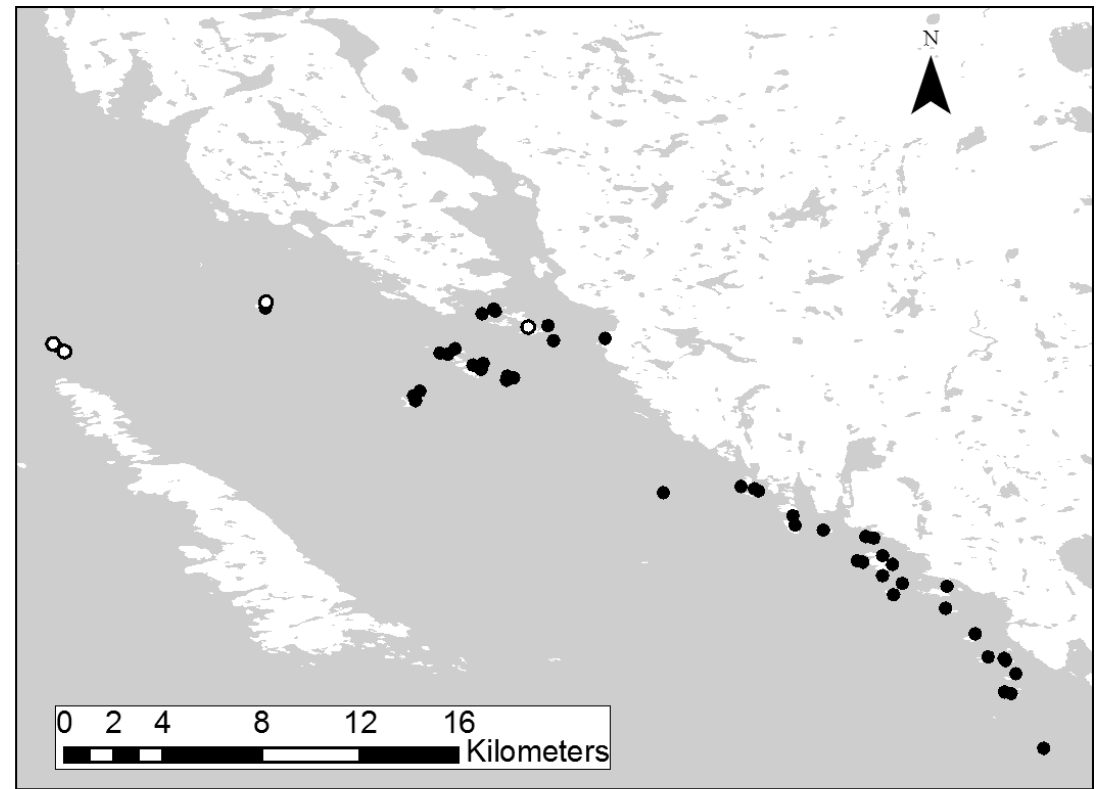

0 Island with $\geq 20$ nesting pairs - Island with $<20$ nesting pairs 
Figure A1.13. Survey zone 13: Southern Frobisher Bay, Frobisher Bay

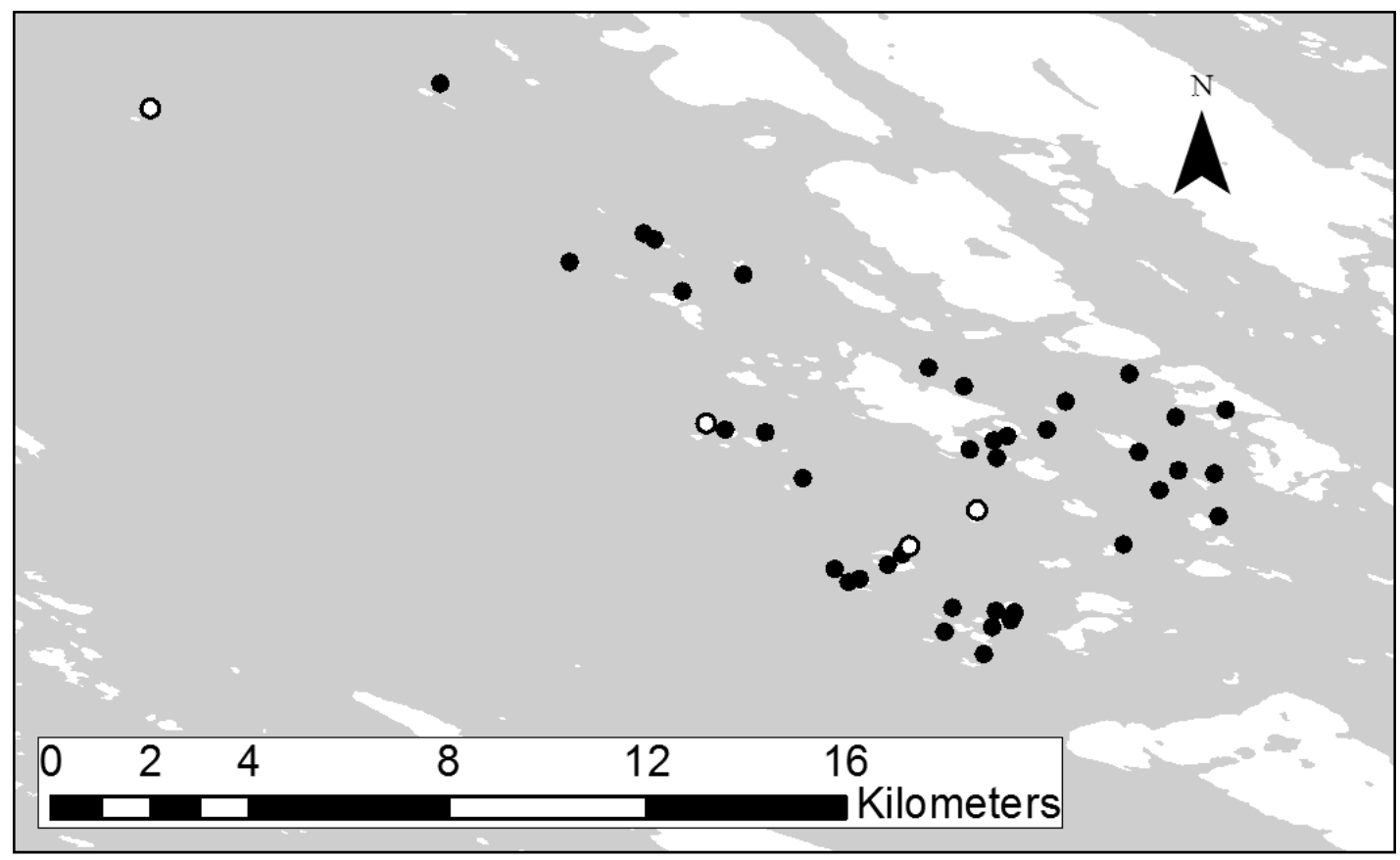

$\circ$ Island with $\geq 20$ nesting pairs $\bullet$ Island with $<20$ nesting pairs

\section{Literature Cited}

Chapdelaine, G., A. Bourget, W. B. Kemp, D. J. Nakashima, and D. J. Murray. 1986.

Population d'Eider à duvet près des côtes du Québec septentrional. Eider Ducks in Canada. Canadian Wildlife Service Report Series No. 47:39-50.

Cooch, F. G. 1986. The number of nesting northern eiders on the West Foxe Islands, NWT, in 1956 and 1976, In Eider Ducks in Canada. Canadian Wildlife Service Report Series 47:114-118.

Falardeau, G., J.-F. Rail, S. Gilliland, and J.-P. L. Savard, J.-P. L. 2003. Breeding survey of Common Eiders along the west coast of Ungava Bay, in summer 2000, and a supplement on other nesting aquatic birds.
Canadian Wildlife Service, Québec Region, Sainte-Foy. Technical Report Series No. 405.

Gaston, A., D. Cairns, and R. Elliot. 1985. A natural history of Digges Sound. Canadian Wildlife Service Report Series No. 46.

Hipfner, J. M., H. G. Gilchrist, A. J. Gaston, and D. K. Cairns. 2002. Status of common eiders, Somateria mollissima, nesting in the Digges Sound region, Nunavut. Canadian FieldNaturalist, 116:22-25.

Robertson, G. J., and H. G. Gilchrist. 1998. Evidence of population declines among common eiders breeding in the Belcher Islands, Northwest Territories. Arctic 51:378385 . 


\section{Appendix 2 - Additional details concerning quantification of site and host population attributes for use in the species-habitat model}

Here we describe the explanatory variables and procedures applied to estimating ecological correlates of Avian Cholera outbreak risk at Common Eider colonies in the Hudson Strait region of the Canadian Arctic

\section{Explanatory variables}

The first category of potential explanatory variable that we considered was the biophysical attributes of the island. Freshwater melt ponds are a potentially important source of Avian Cholera transmission and prospective focal point of management intervention. However, there is considerable variation among islands with respect to pond presence ( $p P O N D$ ) and number (nPOND), as well as other site characteristics, including percent vegetative cover (VEG), island size (AREA), and elevation $(E L E V)$. These variables potentially influence site drainage and the way host species access and move through the habitat.

We quantified pond presence, pond number and vegetative cover directly using visual assessments made by field personnel. Island size and elevation were derived by querying digital thematic maps (CanVec 1:50,000 scale topographic) in ArcGIS (Version 10.1

(Environmental Systems Research Institute Inc., Redlands, CA, USA).

The second category of explanatory variable that we evaluated was focal host quantities. In our model, we included measurements of Common Eider abundance (nCOEl: nests per island) and density (dCOEI: nests per ha) on each island, as well as a quadratic feature quantifying pond abundance in relation to the number of nesting eiders present $(P / 100 E)^{2}$. Inclusion of $(P / 100 E)^{2}$ variable allowed us to consider differences among colonies on which a large number of birds shared a common water source independent of nest density.

The final category of explanatory variable was potential disease dispersers. Our interest was to assess evidence for different species or populations acting as disease vectors or reservoirs. Variables included the presence and number co-nesting gulls, gulls in the surrounding area more generally, and the migration paths of eiders and snow geese converging in Hudson Strait from different wintering grounds. Gull variables encompassed the presence and number of nesting herring gulls ( $p H E R G, n H E R G$ ), the presence and number of nesting glaucous gulls ( $p G L G U$, $n G L G U$ ), and all gulls within a $5 \mathrm{~km}$ radius of the island irrespective of species and nesting status (aGull).

To evaluate the location of colonies in relation to Common Eider migratory flyways we used information from satellite tracking studies conducted by Mosbech et al. (2006), Savard et al. (2011), and G. Gilchrist, Environment Canada (unpublished data). The aforementioned studies were designed to delineate eider movements between wintering and breeding areas and the authors provided us with raw location estimates for birds breeding in the Hudson Strait region.

We processed these data to determine the single highest quality location estimate received during each 2.5 d duty cycle (i.e., the interval when the transmitter unit was programmed to 
be active) during spring migration (15 Apr - 1 Jul). We specified an inclusion threshold of \pm 1 $\mathrm{km}$ accuracy (i.e., Argos location class $\geq 1$ ) and used the first estimate received per duty cycle when multiple estimates of identical accuracy were obtained. The resulting data yielded directional migration paths for 9 eiders ( 7 female and 2 male) tracked from wintering areas in Atlantic Canada into Hudson Strait and 20 eiders ( 16 female and 4 male) tracked from west Greenland into Hudson Strait over a 9 yr span (2000-2004, 2006-2007 and 2012-2013).

We then analyzed the data in Spatial Analyst using the line density tool. Our objective was to calculate track densities within 0.01 degree grid cells throughout the study area (summed migration path length $[\mathrm{km}]$ per unit of area

\section{Literature Cited}

Barry, S., and J. Elith. 2006. Error and uncertainty in habitat models. Journal of Applied Ecology 43:413-423.

Botzler, R. G. 1991. Epizootiology of Avian Cholera in wildfowl. Journal of Wildlife Diseases 27:367-395.

Elith, J., S. J. Phillips, T. Hastie, M. Dudík, Y. E. Chee, and C. J. Yates. 2011. A statistical explanation of MAXENT for ecologists. Diversity and Distributions 17:43-57.

Liu, X., J. R. Rohr, and Y. Li. 2013. Climate, vegetation, introduced hosts and trade shape a global wildlife pandemic. Proceedings of the Royal Society B: Biological Sciences 280(1753):20122506.

Mosbech, A., H. G. Gilchrist, F. Merkel, C. Sonne, A. Flagstad, and H. Nyegaard. 2006. Year-round movements of Northern Common Eiders Somateria mollissima borealis breeding in Arctic Canada and West Greenland followed $\left[\mathrm{km}^{2}\right]$. This enabled us to extract indices of coastline usage by birds affiliated with wintering areas in Atlantic Canada (COEI-CF) or west Greenland (COEI-GF) in the neighborhood of each colony using a search radius buffer of 25 $\mathrm{km}^{2}$ from each island center.

For lesser snow geese, satellite transmitter data was not available; however, patterns of migratory connectivity are well quantified on the basis of harvest recoveries. For our purpose, we overlaid a migration map for mid-Continent lesser snow geese (U.S. Fish and Wildlife Service 2007) onto our study area and again applied a $25 \mathrm{~km}^{2}$ buffer around each island to extract a binary estimate of intersection between eider nesting colonies and lesser snow goose summer distributions ( $S N G O$ ).

by satellite telemetry. Ardea 94:651665.

Mweya, C. N., S. I. Kimera, J. Bukombe, and L. E. B. Mboera. 2013. Predicting distribution of Aedes aegypti and Culex pipiens complex, potential vectors of Rift Valley fever virus in relation to disease epidemics in East Africa. Infection Ecology and Epidemiology 3:21748.

Pearson, R. G., C. J. Raxworthy, M. Nakamura, and A. T. Peterson. 2007. Predicting species distributions from small numbers of occurrence records: a test case using cryptic geckos in Madagascar. Journal of Biogeography 34:102-117.

Phillips, S. J., R. P. Anderson, and R. E. Schapire. 2006. Maximum entropy modeling of species geographic distributions. Ecological Modelling 190:231-259.

Savard, J.-P. L., L. Lesage, S. G. Gilliland, S. G., H. G. Gilchrist, and J.-F. Giroux. 2011. 
Molting, staging, and wintering locations of Common Eiders breeding in the Gyrfalcon Archipelago, Ungava Bay. Arctic 64:197-206.

Slater, H., and E. Michael. 2012. Predicting the current and future potential distributions of lymphatic filariasis in Africa using maximum entropy ecological niche modelling. PloS One 7(2):e32202.

U.S. Fish and Wildlife Service. 2007. Final Environmental Impact Statement - Light Goose Management. Washington, D.C., USA.

Swets, J. A. 1988. Measuring the accuracy of diagnostic systems. Science 240:1285-1293. 